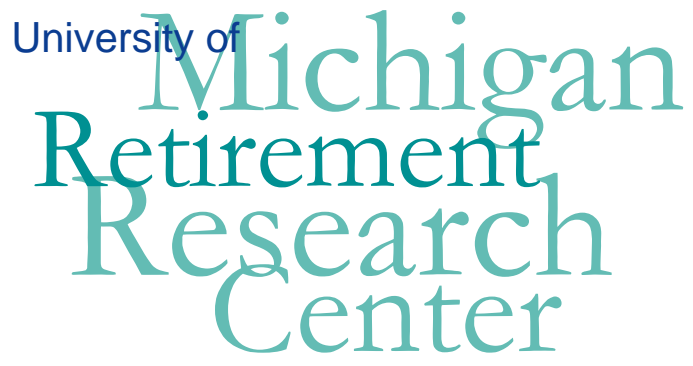

Working Paper WP 2006-137

\title{
The Impact of Health Insurance Availability on Retirement Decision Reversals
}

Joshua Congdon-Hohman

\begin{tabular}{|l|l|l|}
\hline $\mathrm{M}$ & $\mathrm{R}$ \\
\hline $\mathrm{R}$ & $\mathrm{C}$ \\
\hline
\end{tabular}$\quad$ Project \#: UM05-S4 


\title{
“The Impact of Health Insurance Availability on Retirement Decision Reversals”
}

\author{
Joshua Congdon-Hohman \\ University of Michigan
}

October 2006

\author{
Michigan Retirement Research Center \\ University of Michigan \\ P.O. Box 1248 \\ Ann Arbor, MI 48104 \\ http://www.mrrc.isr.umich.edu/ \\ (734) 615-0422
}

\section{Acknowledgements}

This work was supported by a grant from the Social Security Administration through the Michigan Retirement Research Center (Grant \# 10-P-98358-5). The findings and conclusions expressed are solely those of the author and do not represent the views of the Social Security Administration, any agency of the Federal government, or the Michigan Retirement Research Center.

\section{Regents of the University of Michigan}

David A. Brandon, Ann Arbor; Laurence B. Deitch, Bingham Farms; Olivia P. Maynard, Goodrich; Rebecca McGowan, Ann Arbor; Andrea Fischer Newman, Ann Arbor; Andrew C. Richner, Grosse Pointe Park; S. Martin Taylor, Gross Pointe Farms; Katherine E. White, Ann Arbor; Mary Sue Coleman, ex officio 


\title{
The Impact of Health Insurance on Retirement Decision Reversals
}

\author{
Joshua Congdon-Hohman
}

\begin{abstract}
This paper uses the longitudinal aspect of the Health and Retirement Survey to explore the characteristics associated with reversals in retirement (referred to here as "unretirement"). Through the use of survival time analysis, this paper show that health insurance plays a significant role in unretirement decisions. This role is underestimated when a static probit analysis is used alone. The results hold up for a number of different retirement identifiers that are based both on self-reports of retirement and actual work levels. The results are also robust to various definitions of retirement prompted by the difficult question of how to classify partial retirements. The importance of health insurance provision in a retiree's decision also remains significant when other "shocks" and the prospect of planned unretirement are introduced.
\end{abstract}

\section{Authors' Acknowledgements}

The author would like to thanks Charlie Brown, George Johnson, Jeff Smith, Ann Ferris, Laurie Pounder, Hwajung Choi, Amy Kandilov and Jon Lanning of the University of Michigan for their very helpful comments and assistance. Further comments are greatly appreciated. 


\section{Introduction:}

Most research in the area of retirement has focused on an individual's decision to retire or continue working. Debate in the field tends to focus on what model best fits retirement decision behavior. What is often neglected is the fact that an individual's working career does not always end with retirement. Many retirees choose to return to work either on a part-time or full-time basis after fully retiring, or return to full-time work after partially retiring. This paper examines which indicators are linked to the choice of retirees to go back to work after retiring, and specifically how much impact the lack of health insurance provision in retirement has on that decision. The Health and Retirement Survey (HRS), produced by the Institute for Social Research at the University of Michigan, provides a unique opportunity to study this question. Due to the longitudinal nature of the survey, individuals can be followed and examined over a fourteen-year period. After controlling for other potential characteristics that may be associated with leaving retirement, such as health changes and other "shocks," indications that a respondent planned to work in retirement and demographic characteristics, this study will show using both simple probit and survival time models that the provision of health insurance has a dramatic effect on one's decision to return to the work force or to increase the level of work that the retiree does. For the purposes of this paper, retirees who choose to return to work will be termed "unretirees." Those who retire and do not return to work in the observation period will at times be referred to as "permanent retirees." A discussion of the appropriate definition of unretirement will follow in a subsequent section. 
The use of a survival time model has significant implications for our ability to get closer to the root causes of unretirement. Previous studies have used stationary models to explain future unretirement behavior. More specifically, researchers have used the characteristics of retirees at the time of retirement to predict behavior in the future. This approach does not allow for changes to key indicators or for shocks. This study will allow many indicators to vary with time during retirement in survival time models and compare the results to the static results produced from simple probit models. In addition to indicators for the possession of health insurance and its source, time variant indicators of interest include health measures, the receipt of a pension, and changes to wealth, medical costs, and the retirement status of one's spouse.

The next section of this paper describes recent trends in health insurance premium costs and employer provision of insurance as a retirement benefit. Section III presents a summary of past work on retirement models and work on the importance of health insurance for labor force decisions. Section IV discusses the various definitions and identifiers used for retirement and unretirement. Section V describes the data used and sample restrictions. Section VI discusses the characteristics of interest and raw differences between permanent retirees and future unretirees. Section VII presents the results and is followed by our conclusion. 


\section{$\underline{\text { II. Employer Provided Health Insurance and Industry Trends }}$}

The problem of health insurance coverage for early retirees ${ }^{1}$ has grown over recent years as fewer employers offer these benefits to their retirees while the cost of private insurance for older individuals is growing faster than health insurance premiums for other groups. The risks associated with being uninsured are also increasing as medical care costs rise dramatically faster than inflation. According to an Employees Benefits Research Institute report, the percent of early retirees in the Survey of Income and Program Participation (SIPP) receiving health insurance from their former employer has dropped from 39.2 percent in 1997 to 28.7 percent in 2002 (Fronstin, 2005). A joint 2006 survey by the Kaiser Family Foundation and the Health Research and Education Trust found that the percentage of large firms (over 200 workers) that offered retiree health coverage fell from 66\% in 1988 to 35\% in 2006 (Kaiser, 2006). Retirees are also able to continue their health insurance under the rules codified in the Consolidated Omnibus Budget Reconciliation Act of 1986 (commonly referred to as COBRA benefits). COBRA allows all workers to continue their former benefits at 102 percent of the cost to the former employer for 18 months. The Government Accounting Office (GAO) reported that the percent of large employers offering health insurance to retirees fell from between 60 and 70 percent in the 1980's to 40 percent at the time of its report (GAO, 1998). Additionally, the report cited a Labor Department report that stated that 2 percent of 1994 retirees lost their promised retirement benefits in the following years. Though this number is small, that report was issued at a time of economic expansion and

\footnotetext{
${ }^{1}$ Here defined as those retiring before 65 when individuals become eligible for government-provided Medicare health benefits
} 
anecdotal evidence more recently suggests that more firms are eliminating health insurance benefits to currently retired individuals.

Given that retirees do not qualify for Medicare coverage until they turn 65 unless they have a qualifying disability, early retirees without an employer provided health insurance option are left with the choice of finding an alternative source of health insurance or going without coverage. Low cost alternatives include veteran’s benefits, trade union group policies and insurance provided through a spouse's employer. Another possibility is to find an individual policy with a private carrier, but this option tends to be extremely expensive and usually does not cover preexisting conditions. A 1996 GAO study reported that individuals between the ages of 60 and 64 are two-and-one-half times more likely to be self-insured than people in their twenties. The same study points to individuals between the ages of 60 and 64 as having the most expensive premiums, ranging from $\$ 210$ to $\$ 532$ per month in a survey of a few individual policy providers (GAO, 1996). In another report, the GAO stated that a healthy 60 year-old man might pay close to four times the premium of a healthy 30 year-old man (GAO, 1999). Those who can buy into their former employer-provided programs (through COBRA or special arrangement) benefit from lower premiums than they could get on their own, but the premiums for these plans are also quite expensive and rising dramatically. The aforementioned 2006 Kaiser health benefits survey found that employer health insurance premiums averaged $\$ 4,242$ per year for a single individual and $\$ 11,480$ for a family plan in 2006. This level of premiums represents an $87 \%$ increase from the premiums found in the same survey in 2000 (Kaiser, 2006). 


\section{$\underline{\text { III. Previous Work }}$}

The most prominent retirement models are based on a life-cycle consumption to leisure tradeoff and focus on the expected benefit of delaying retirement. The models tend to differ in how they evaluate the expected benefit of delay. One of the early models in this area, proposed by Alan Gustman and Thomas Steinmeier, used previously established life-cycle utility maximization models and examined the expected impact of an additional year of work on expected utility (Gustman \& Steinmeier, 1986). James Stock and David Wise introduced a different approach that focused on the "option value" of remaining employed for one additional year. In this model, Stock and Wise compared the expected present value of retiring today to the expected present value at all future ages, not just the following year (Stock and Wise, 1990). A more complex version of the dynamic programming approach described above is a stochastic dynamic programming model, which compares the expected value of the maximum of future options compared to the current option value (Lumsdaine and Mitchell, 1999). None of these models allow for the potential retiree to return to work, either planned or unplanned, following retirement. One of the few dynamic programming models that allows for the possibility of unretirement was proposed by James Berkovec and Steven Stern (1991). In their model, Berkovec and Stern allowed an individual in retirement to choose between remaining retired, working full-time, or working part-time. In an attempt to simplify their complex model, the authors allowed for very little uncertainty in future wages and no uncertainty in the area of future health. They also excluded the Social Security system entirely. 
The importance of health insurance coverage has been an area of interest in many empirical studies that analyze retirement decisions. Many studies have found that the availability of health insurance benefits for early retirees encourages workers to leave the work force. Similarly, the spike in the retirement hazard rate at the age of 65 , when individuals become eligible for Medicare, is well documented. ${ }^{2}$ Gustman and Steinmeier (1994) used a number of 1970's and 1980's survey data to test the importance of current employer provided health insurance when applying their retirement model. They found that having current employer-provided insurance may delay retirement slightly, but that ignoring such benefits in retirement models only introduces slight bias. Lynn Karoly and Jeannette Rogowski (1994) used SIPP data from the mid to late 1980’s and a simple static model of retirement to show that employer-provided retiree health benefits contribute to a higher rate of retirement before the age of 65 (about 50 percent higher than those without such a benefit). Jonathan Gruber and Brigitte Madrian (1995) used the Current Population Survey (CPS) and SIPP data to evaluate the impact of state mandated health insurance coverage after leaving an employer (similar to the later passed federal COBRA benefit guarantees). They found that for men aged 55-64, a one-year continuation of health insurance raised the retirement hazard rate by 30 percent. Using the 1992 through 1996 waves of the HRS, Rogowski and Karoly (2000) found that individuals with employer-provided retiree health insurance were 68 percent more likely to retiree than those without it. Also using the HRS, David Blau and Donna Gilleskie (2001) found that employer provided retiree health insurance increased the likelihood that an individual retires by two to six percent for men from age 51 to 62, depending on how

\footnotetext{
${ }^{2}$ Supported by the finding of Rust and Phelan [1997], though Lumsdaine, Stock and Wise [1992] and Madrian and Beaulieu [1998] have found contradictory evidence.
} 
much of the cost is shared between the employer and the employee. Richard Johnson, Amy Davidoff and Kevin Perese (2003) used the 1992 and 1994 waves of the HRS to show that full-time female and male workers between 51 and 61 years of age in 1992 have a 26 percent and 31 percent higher retirement rate, respectively, if they have retiree health insurance. Hugo Benitez-Silva and Frank Heiland (2003) also found that retiree health insurance increased the likelihood of early retirement using the first three waves of the HRS. In addition, they found that having health insurance had a negative effect on the chances that a nonemployed (not just those declaring themselves to be retired) individual would return to work.

Work on unretirement is much more limited. For the most part, estimates of the unretirement rate are left as a footnote to discussions of the retirement hazard rate. Christopher Ruhm (1990) found that over one quarter of retirees in the Retirement History Longitudinal Survey (RHLS) “reverse retire” and a similar number return to full work after partially retiring. The RHLS followed a random sample of individuals aged 58-63 in 1969 until the survey ended in 1979. Of those who unretired from full retirement, Ruhm found that two-thirds moved to partial retirement and that over threequarters did so in the first four years of retirement. He also found that those with pensions and higher levels of education were less likely to unretire than others when controlling for income, age, and gender. Additionally, he found that married individuals were significantly more likely to reverse retire. Health care costs and insurance provision were not addressed in Ruhm’s work.

In a more recent study using the first five waves of the HRS, Nicole Maestas (2004) focused on unretirement decisions. She found that 24 percent of retirees in the 
sample return to work within five years of retirement. Additionally, individuals retiring at the ages of 51 or 52 unretired at a rate of 36 percent while only 16.7 percent of those retiring at 65 or 66 unretired. The main conclusion of her work is that unretirement decisions were anticipated and not associated with poor planning or inadequate retirement resources. In addition to a positive and significant coefficient on an HRS question in 1992 that asks if an individual plans to work in retirement, Maestas pointed out that eighty percent of future unretirees answered in the affirmative compared to only 68 percent of those who did not plan on going back to work.

\section{Identifying and Defining Retirement and Unretirement}

Retirement and unretirement are identified in a number of ways for this study, using two variables for designating retirement status. The first reflects the self-reported retirement status of individuals who are asked whether they consider themselves to be “fully retired, partly retired, or not retired at all." The RAND dataset is the direct source of this data but it has taken these values almost directly from the HRS data. A large portion of the values for this variable were coded as "Question Irrelevant.” This response could be based on a prior response (such as work status) or because the respondent does not consider him or herself part of the labor force (if a homemaker or disabled, for example). In the instances where the response is coded as “Question Irrelevant,” the respondent is assumed to continue to be retired if he or she was retired in the previous wave. If the respondent was not retired in the previous wave and the next meaningful response (i.e. not missing or coded as irrelevant) is retired, the value is changed to correspond with any retirement date given elsewhere in the survey. For example, if a 
respondent self-reports not being retired in 1992 (wave 1), reports the question to be irrelevant in 1994 and 1996, and self-reports being “fully retired” in 1998 with a retirement date in the year 1995, the “question irrelevant” response in 1994 is changed to "not retired at all" and the 1996 value is converted to be the same as the 1998 value. If this method fails to assign a value to the irrelevant response, it is given the value of the last non-irrelevant response.

The second variable that will be used to identify retirement is a RAND derived variable to represent labor force status. RAND attempts to correct for discrepancies between respondents’ self-reports of retirement status and their work activity by using a number of survey questions. By using variables that ask whether an individual is working for pay, is seeking work, and whether she considers herself retired (in addition to other variables), they have constructed a rubric to define an individual's labor status. Specifically, if a person works full-time (considered to be 35 hours or more per week and at least 36 weeks per year), she is considered working regardless of her self-reported retirement status. If respondents are not working full-time and mentions that they consider themselves retired, RAND determines their labor force status by their hours and weeks worked regardless of whether they considered themselves fully or partially retired. Respondents were only classified as fully retired if they reported partial or full retirement in one of two places in the survey (the self-reported retirement status question discussed above or in a separate labor force question) and did not work for pay. If a respondent reported being fully or partially retired and either worked on a part-time basis ${ }^{3}$ or did not work for pay but reported looking for part-time work, RAND classified him or her as partially retired. Other labor force statuses defined when retirement is not mentioned

\footnotetext{
${ }^{3}$ Defined as working for pay but not meeting the hours or weeks requirement to be considered full-time.
} 
include working part-time, unemployed, disabled, and not in the labor force. Allowing people to be classified as unemployed, disabled, or not in the labor force adds some ambiguity to the dichotomy of retired versus working. The first question is how to classify people who have a wave with an ambiguous labor force status between two waves where they are classified as retired. For the purposes of this analysis, only changes in labor force status from a retired state to a working state will be considered unretirement. A second issue to address is how to time the beginning of a retirement if a respondent transitions through one of these ambiguous labor force statuses between working and unretiring. The timing of retirement in these cases does not affect whether one is classified as unretired at some point in the observed period since these transition periods cannot contain any reversals by definition. But, this timing may affect whether one remains in the sample given the sample restrictions discussed in the next section. To handle these transitions through an ambiguous state, respondents are assigned retirement states during these waves using a method similar to the one discussed above for "question irrelevant" responses to the self-reported retirement status question. Retirement dates are used to determine whether to predate the retirement to the ambiguous response wave or to begin the retirement at the wave where full or partial retirement is reported as the respondents labor force status.

Table 1 shows how the retirement status of respondents based on the two identifying variables differ. The stark majority of values agree with $88 \%$ of all retirement statuses for both variables being equivalent and 93.5\% if missing values are excluded. There are almost equal numbers of responses where RAND considers a respondent more retired than his or her self-reported retirement status (e.g. fully-retired rather than 
partially-retired or not retired) and cases where RAND downgraded an individual's selfreported status (e.g. working rather than partially- or fully-retired). Most of these discrepancies are due to the number of hours and weeks worked by the respondent. The cases where the respondent's self-reported retirement status is not retired but his or her RAND labor force status is full or partial retirement are due to the fact that retirement can also be announced in a second question asking for all labor force statuses that apply. ${ }^{4}$ The large number of missing values for the self-reported retirement question is predominantly due to the skip pattern of the HRS survey. Most of these are eliminated from the sample due to reasons other than the fact that they have a missing value. ${ }^{5}$ These missing values are distributed relatively evenly across the waves of the study. The bulk (about 95\%) of those with missing self-reported retirement values appear to be working, but given the large number of people who consider themselves partially or fully retired despite their level of work, it seems inappropriate to assign these individuals a working status without knowing their underlying opinion about their retirement status.

When considering how to define unretirement, one must consider how to treat partial retirement. Partial retirement could be considered a form of retirement in that it is the first step in the retirement progression where the worker reduces her hours in her career job, or more likely in another job. Alternatively, one might consider partial retirement just another form of continuing one’s working life before she stops working entirely in full retirement. Rather than chose one position, this study runs separate

\footnotetext{
${ }^{4}$ I.e. Respondents have reported that they do not consider themselves retired in one question but then give "partially retired" or "fully retired" as a labor force status elsewhere in the survey. RAND uses the same hours and weeks worked criteria for assigning labor force status in this case as discussed previously.

${ }^{5}$ The portion of the sample lost dropped from $6 \%$ of the whole universe of responses with missing selfreports to $4 \%$ of the subset in either of the two primary samples, including the one based on the RAND labor force status.
} 
analyses for each. Where a response of partial retirement can identify the onset of retirement, a directional definition of unretirement is used. A respondent would have to move from a higher to a lower state of retirement to be considered unretired. The highest state of retirement for these purposes would be full retirement, followed by partial retirement and not retired (which would be the lowest state). For example, if one is fully retired in the previous wave, she would be considered unretired if she moves to either a partially retired or not retired state, but only moving to a "not retired" state would be considered unretiring for a respondent who was previously partially retired. Using full retirement alone to define retirement allows for a more straight-forward definition of unretirement. In this case, any change from fully retired to partial retirement or not retired is considered unretirement.

\section{Data:}

The "Initial" cohort of the Health and Retirement Survey tracks individuals between the ages of 51 and 61 in 1992, as well as their spouses, and records a wealth of data on income, employment, retirement, and health measures among many other things. The "War Baby" (WB) cohort was added to the HRS in 1998 and includes individuals born between 1942 and 1947 (and thus between 51 and 56 at the time they are first observed). These individuals have been reinterviewed every two years since 1992 and 1998, respectively, with the most recent available data from $2004 .^{6}$ In an attempt to make the HRS data more accessible, the RAND Center for the Study of Aging has created data

\footnotetext{
${ }^{6}$ Three additional cohorts of the HRS exist and have been excluded from this study. Two of these cohorts are much older and would not be expected to have much labor force contribution (the "Ahead" cohort was born before 1923 and the "Children of the Depression" cohort between 1924 and 1930). The third is a later cohort, the "Early Baby Boomer," that was born between 1948 and 1953 and may have been interesting but was first surveyed in 2004 and thus only have one data point.
} 
files with some variables cleaned to cut down on contradictory reports and to create compatible variables across waves since some survey questions changed from wave to wave. It has also created a number of summary variables that are quite useful in this study. With the exception of the data regarding health insurance coverage in this paper, most data values have come from the RAND dataset. The health insurance and coverage data has come directly from the HRS raw files due to the more detailed information that those original files contain.

The Initial cohort covers the group of individuals that are between 51 and 73 over the fourteen years that they are followed for this survey and those in the War Baby cohort are between 51 and 62 over their eight years of coverage. Spouses are included in the HRS surveys, but are only included as separate observations here if they would have been age-eligible for one of the two cohorts. There are a few spouses in the Initial cohort who would have been age eligible for the War Baby cohort and vice versa. These respondents have been retained in the sample if not omitted for some other reason. The span of ages covered is consistent with the age range when individuals begin to consider both early retirement and traditional retirement.

Additional restrictions are put on HRS respondents in the Initial and War Baby cohorts to arrive at the sample used in this study's analysis. Because this study uses information from the time of retirement and controls for any duration bias, individuals are required to be observed and working in the first wave that their cohort is surveyed. ${ }^{7}$ In order to be included in the sample, an HRS respondent must be observed and have a non-

\footnotetext{
${ }^{7}$ Limiting the analysis sample to only those present in the sample at the cohort's first wave eliminates those who might join the household after the initial contact. There are some questions that are only asked at the baseline interview and would thus not be included for these individuals. Also, they could not be observed for the full range of years if they were not present in the first wave.
} 
missing value for her retirement status in every wave. With this limitation, the question of what to do with missing values is avoided, but the question of selection bias is a valid concern. Missing retirement values were discussed in the previous section. Those respondents who are omitted from the sample for having non-responding waves can be separated into those who are deceased and those who attrite. The deceased are no longer interesting to a paper focused on decisions about labor force participation since death severely does not allow for choices. The reason for non-death attrition leaves much more cause for concern.

Table 2 shows any baseline ${ }^{8}$ interview demographic differences between those who attrite for reasons other than death and those that remain in the ultimate analysis sample. When comparing means, their significance will be evaluated based on whether the hypothesis that the two means are equal can be rejected with a 95\% level of confidence using a simple t-test. There is not a statistically significant difference in age, marital status and the percentage working at their first observed wave between the two groups. Those in the final sample are significantly more likely to be female and healthier, which could potentially be evidence of attrition due to unobserved death since men have a lower life expectancy and self-rated health is a proxy for actual health. ${ }^{9}$ Racial, educational, and regional differences also exist between those remaining in the sample and those attriting. Attriting respondents are more likely to be non-white or Hispanic, less educated, and from the North or Midwest. ${ }^{10}$ It is not clear what type of bias this may add to our results.

\footnotetext{
${ }^{8}$ The baseline interview is 1992 for the Initial cohort and 1998 for the WB cohort.

${ }^{9}$ HRS surveyors have done their best to identify those who are deceased but cannot be certain in many cases of non-response.

${ }^{10}$ Probably lost due to a move to warmer climates.
} 
As Table 3 shows, the Initial HRS cohort consists of 13,367 individuals in 1992 (over 7,600 households) and the WB cohort includes 2,694 respondents. Eliminating from the sample those who are not age eligible for either cohort reduces the full sample by $15 \%$ with a higher rate of WB cohort individuals being ineligible than in the Initial HRS cohort. Of those who are age eligible, about $12 \%$ die sometime during observation. The bulk of these are in the Initial cohort of the HRS which is not surprising given that they are followed for a longer period of time and are older when observed in 2004. Thirty percent are lost to attrition for reasons other than observed death, again primarily in the Initial cohort. The requirement that respondents be working in the first wave of observation reduces the sample by an additional $25 \%$.

Due to the fact that this study uses a number of definitions and identifying variables for retirement, the sample is slightly different for each. The bottom section of Table 3 shows the differences in sample size for each specification. Because the selfreported retirement status variable has a larger number of missing variables (as discussed above), the requirement that there be no missing retirement values has a larger impact on the self-report sample (losing about $13 \%$ of the remaining sample) than the RAND derived labor force status sample (which has no missing values). Finally, since this study focuses on the respondent's decision to return to the work or increase his or her level of work, the samples are limited to only those observed to retire and given at least one wave of opportunity to be observed returning to work. Using the directional, self-reported retirement definition discussed above, the sample shrinks by an additional 35\% for those in the Initial cohort and almost $85 \%$ for those in the WB cohort due to their shorter period of observation and younger final age. The full-retirement only definition reduces the 
sample further since those who transition through partial retirement are not considered retired until they become fully retired, which delays the beginning of their retirement observation period. Using the RAND labor force status definition creates similar reductions in the sample size under the directional definition (37\% for the Initial cohort and $86 \%$ for the WB cohort). The final samples range from $19 \%$ of the original sample (RAND labor force status identifier with directional definition of retirement) to $12 \%$ of the original sample (self-reported retirement using a full retirement only definition of retirement).

When focusing on decisions made solely during the traditional early retirement period (before respondents become eligible for Medicare), the sample only includes waves where the respondent is under 65 at the time of taking the HRS survey. Again, in order for those in the sample to have at least one opportunity to unretire, the sample is restricted to those who are observed for at least one wave after their retirement while still less than 65 years of age. Most of the additional reduction in the sample for those respondents less than 65 years of age is from the Initial HRS cohort since most of the WB cohort is under 65 for the full observation period. ${ }^{11}$ Final “under-65” samples range from $7 \%$ of the full sample (self-reported, full retirement definition) to 12\% (RAND labor force status, directional definition).

Table 4 shows the differences in the portion of the sample unretiring for the two retirement defining variables and the two unretirement definitions. Though the unretirement portion for the full qualified sample ${ }^{12}$ is very similar between the selfreported retirement and labor force variables with either unretirement definition (around

\footnotetext{
${ }^{11}$ The exception being those spouses in the WB cohort who would have been age eligible for the Initial HRS cohort

12 "Qualified" is discussed in the following section.
} 
$30 \%$ for the directional definition and $25 \%$ for the full retirement only definition), the below 65 years of age restriction introduces a three to four percent difference between the two retirement identifiers (27.4\% for self-report and 23.3 for labor force status using the directional definition, $23.2 \%$ and $20.4 \%$ for the full-retirement only definition). At first glance it may seem surprising that the subset of respondents retiring before their 65th birthday would have a lower unretirement portion than the full sample. The reason for this counter-intuitive result is more a function of the sample restrictions than an underlying surprising fact. As will be discussed in the next section, the under-65 sample is restricted to waves where the respondent is under 65 so any unretirement after age 65 is not included. The relationship across cohorts of the portion of the sample unretiring is generally as one would expect given the sample limitations. The unretirement portion among those in the Initial HRS cohort closely resembles the full sample rates due to the fact that they make up most of the full sample. The WB cohort shows slightly more variability but is relatively consistent with the full sample pattern. ${ }^{13}$

The range of unretirement portions found in the full sample, Initial HRS and WB cohorts (between 25\% and 31\%) are in line with similar statistics found in the few other studies focused on this topic. Ruhm (1990) found that twenty-five percent of those observed over a certain minimum number of years reverse retired out of full retirement and a similar number reverse retired out of partial retirement (26 percent became not retired after partially retiring). Maestas (2004) also found a similar figure of 24 percent

\footnotetext{
${ }^{13}$ One might ask how the unretirement portion for the full retirement definition could be higher than the directional definition as it is for the War Baby cohort using the self-report identifier. Though individuals moving from partial retirement to not retired are no longer counted in the numerator, they are also excluded from the denominator since they are not considered retired until they identify themselves as fully retired. In this case it appears that a higher percentage of "full" retirees increase their work level at a later wave than those who are only "partially retired".
} 
unretiring using data from the first five waves of the Initial HRS cohort. She solely used the RAND labor force variable and a directional definition of unretirement.

\section{Comparing Those Who Unretire to Those Who Remain Retired:}

Before moving into the formal analysis of the predictors of unretirement, it is worthwhile to explore the characteristics of those who decide to increase their work status. Table 5 shows that there are many significant differences at the time of first retirements between those who go back to work after retiring and those who do not. The table presents the mean values for key demographic characteristics for permanent retirees and future unretirees along with the t-statistic for the difference in the means between the two groups. Future unretirees tend to be significantly ${ }^{14}$ younger (a little over a year difference for both retirement identifiers) than their permanent retiree counterparts at the time of their retirement. Though there is not a significant difference between the percentage that are married and a significant difference only for the labor force identifier based on gender. However, married males are significantly more likely to return to work than single males and women. Respondents whose spouses are also retired when they retire are more likely to remain retired throughout our observation period than those without spouses or whose spouses are not retired. As one might expect, individuals who rate their own health as "poor" or "fair" at their first observed retirement wave are significantly less likely to increase their working status than those who rate their health as “excellent,” “very good,” or “good,” but the self-rated health of a respondent's spouse is not significantly different for the two groups.

\footnotetext{
${ }^{14}$ Unless otherwise noted, significance is evaluated at the 95\% confidence level.
} 
Major differences between the samples identified by the two retirement indicators are more common when looking at differences in race and educational attainment. Race is a more significant outcome predictor for those whose retirement is defined by their self-reported retirement status rather than their RAND derived labor force status. In the case of the self-reports, individuals identifying themselves as white tend to be less likely to unretire while those identifying themselves as of "other race" tend to be more likely to return to work. None of the race indicators are significantly different under the labor force definition. The opposite is true for the two indicators when looking at educational attainment. Self-reported unretirement seems to have no significant link to attainment while the labor force defined unretirement is significantly less likely among people who do not finish high school than those that do. Particular levels of educational attainment after high school are not significant indicators of future retirement behavior under either retirement identifier.

Table 6 compares characteristics of particular interest both across retirement identifier and across analysis method. The probit analysis focuses on the value at a respondent's retirement wave or, in the case of "shocks," at the change in the value of a variable between the retirement wave and the following wave. The survival time analysis uses the previous wave's value of indicators and changes between the previous wave and the wave prior.

The health insurance provision and pension variables are almost uniformly different between permanent retirees and future unretirees. Retirees who do not have any form of health insurance (including government-provided as well as through a spouse, former employer or trade union) are consistently more likely to return to work or increase 
their work level than those who do have some form of health insurance, whether this is measured at retirement or in the wave prior. The same is true among those who purchase their health insurance directly from a private insurer and thus do not have access to the reduced costs for health insurance associated with group policies. ${ }^{15}$ Purchasing health insurance through a current (for partial retirees) or former employer but paying the full cost is the only source of health insurance that does not appear to be significantly different for permanent retirees and future unretirees in all cases. Though future unretirees are more likely to purchase insurance through an employer at retirement when retirement is identified using the RAND derived labor force status, the hypothesis that the two means are equal cannot be rejected with 95\% confidence. If instead previous waves values are used, the same hypothesis can be rejected. Whether the respondent receives a pension benefit in their retirement wave or in the previous wave is significantly different for permanent retirees and unretirees.

Table 6 also contains the difference in means of various "shocks." Here, shocks are changes in circumstances that may not be reflected in initial values at retirement. Due to the different nature of the probit and survival time analyses, shocks are defined differently for each. Since the survival time model allows for varying values across time, it is natural to define shocks as the change between the previous wave and the wave prior. For the probit analysis, this study instead focuses on the immediate shocks that may follow retirement by looking at changes between the values at the wave of retirement and the following wave (the first opportunity individuals have to unretire). A shock to wealth is defined as losing $50 \%$ of one's reported total wealth with a minimum change of at least

\footnotetext{
${ }^{15}$ Such as those available to employers and trade unions
} 
$\$ 10,000 .{ }^{16}$ When looking at a shock between the retirement wave and the following wave, future unretirees were significantly more likely to have had such a shock in every defined grouping except for the self-reported retirement definition. The mean rate of reporting self-rated health declines of two levels or more ${ }^{17}$ is only significantly different between the two groups in the RAND derived labor force defined group with probit analysis shocks. An increase in household size after retirement is significantly more prevalent for future unretireesunder both retirement identifier specifications. An increase in out-of-pocket medical expenses of fifty percent or more and at least $\$ 2,000$ does not appear to be significantly different for the two groups of retirees under any definition or analysis type.

Additional attention is paid in this study to a specific question in the Initial HRS wave that asked respondents whether they planned to do "paid work in retirement." Though this does not directly refer to unretirement, since a transition through partial retirement would also seem to be included in this expectation, it has been the focus of previous work on the subject of unretirement and has proven to be quite powerful in predicting retirement status reversals (Maestas, 2004). At least in comparison of means, this seems to hold true as future unretirees are significantly more likely to have reported plans to unretire when asked in the 1992 wave. $^{18}$

\section{Analysis:}

\footnotetext{
${ }^{16}$ The amount of loss requirement is due to the fact that a loss of $50 \%$ of ones wealth is very different if a respondent begins with $\$ 1000$ of wealth rather than $\$ 100,000$.

${ }^{17}$ Self-rated health can be evaluated at one of 5 levels in the HRS: "excellent," "very good," "good,” "fair" or "poor". A two level drop would include going from excellent to good, fair or poor, from very good to fair or poor, or from good to poor.

${ }^{18}$ It is worth noting that this question was only asked in 1992, the initial wave, so is only available for those in the initial cohort. Since this is the bulk of the sample, few observations are lost when it is used but the distribution of ages no longer includes the younger group represented by the War Baby cohort.
} 
The analysis in this study is done in parallel for probit and survival time (also commonly referred to as duration) methodologies. The probit analysis is done to measure the significance of various characteristics at retirement in predicting future unretirement in any wave before the HRS survey ends. ${ }^{19}$ Because probit analysis does not have a time element, it cannot handle changes in the probability of unretirement related to the length of observation, often called duration bias. Respondents are first observed as retired at different waves and thus have varying lengths of observation. As a result, those who retire in the second wave of the HRS (the first possible time they could retire given the sample restrictions) have five opportunities to be observed as unretired while those who retire in wave six only have one wave where they may be observed as unretired. In an attempt to reduce this bias, all probit analyses include "Wave retired" dummies as a way to capture differences in the "time at risk" of unretirement. Additionally, the probit analysis does not account for censoring. Those who have not unretired before they are censored are assumed to never unretire in this type of analysis.

The survival time analysis is designed to account for censoring (in this case from the end of survey) and account for varying lengths of observation and is also better equipped to evaluate the effects of shocks and other changes to a respondent's maximization problem since the values can change with time. This design element is one of the reasons why survival time models are commonly used in unemployment and welfare spell duration as many individuals do not become employed or get off welfare before the time of observation ends (if those events ever happens). Because it is expected that respondents are less likely to unretire the longer they are retired, the survival time

\footnotetext{
${ }^{19}$ This is the only form of censuring for this sample since all respondents with a missing wave are omitted from the sample.
} 
specifications used in this study use a Weibull distribution in order to account for the expected negative duration dependence (Wooldridge, 2002). More specifically, the hazard function (the likelihood that one will unretiree in a particular wave given one has not unretired in any of the previous waves) is not assumed to be constant over time and in fact becomes smaller the longer one has been retired.

Generally, values are evaluated at the first wave that retirement is reported for the probit analysis and measured at the previous wave for survival time analysis. Previous wave values are used in the survival time analysis to avoid simultaneity bias for those who unretire since they are not observed just as they change their work status, but 1 day to 2 years after. The previous wave values are the best look at what respondents' conditions were like at the time of unretirement. Also, previous wave values are necessary in the case of benefits (such as health insurance and pensions) that may change because one returned to work rather than being responsible for it. As discussed in the previous section, changes in characteristics, such as health or wealth, are measured on different ranges of time in the probit and survival time analyses. In the probit case, characteristics are evaluated based on the change from the retirement wave to the wave following. In the survival time analysis, changes are measured between the previous wave and the wave prior. Unfortunately, in the probit analysis this method leaves open the possibility of introducing some bias for those characteristics that may be affected by a return to work in the first wave after retirement. For example, changes to wealth will be related to whether one returns to work in the first wave after retirement or not since they will be drawing an earned income if they are working. Similarly, self-rated health may be affected by working. In the case of financial changes, the bias should be in the 
opposite direction of the expected significance, ${ }^{20}$ so any estimate should be a lower bound for the true value and thus a significantly positive result implies a larger significant positive result if it were not for the bias. Similarly, for health shocks, it would be expected that those who experience sudden ${ }^{21}$ onsets of poor health are less likely to be able to return to work and thus less likely to unretire. If returning to work makes individuals feel worse about their health due to the rigors of a working schedule and the stress related to working, respondents who unretire will be more likely to report drops in health in the wave they return to work, thus introducing bias in the positive (more likely to unretire) direction. Therefore, the probit analysis value for this characteristic is an upper bound on the negative effects that may be associated with a negative health shock.

Probit analysis results are presented as the marginal impact on the probability of an event if all other values are evaluated at their means and there is either a one unit change if the variable is continuous or a change from zero to one if the variable is a binary value. Survival time analysis results are presented as a hazard ratio. The numerator of the ratio is the value of the hazard if an observation has the associated characteristic and the denominator is the value of the hazard if that characteristic is not present if the value is binary. If the value is instead continuously valued, the ratio is that of the hazard with and without single unit changes around the mean. Characteristics have a positive impact on the hazard rate if the hazard ratio has a value greater than one and a negative impact if the ratio is less than one. Though these two measures may not be directly comparable, the marginal impact can be converted to a naïve probability ratio.

\footnotetext{
${ }^{20}$ For example, if an individual lost over $50 \%$ of his or her wealth, and returned to work, the positive income earned could increase his or her wealth so that by the time they are observed, they no longer appear to have lost $50 \%$ of their wealth and the unretirement will not be associated with this variable.

${ }^{21}$ Here, "sudden” means within a two-year period due to the restrictions of the HRS survey's frequency.
} 
This estimate can be reached by taking the overall probability of unretiring for the appropriate unretirement definition and retirement identifier from Table 4, adding or subtracting the value of the appropriate coefficient (depending on the sign of the coefficient), and then dividing by the overall probability.

Table 7 presents the association of demographic, health and wealth characteristics with future unretirement under both types of analysis, both retirement identifiers and both unretirement definitions for the full sample. Table 8 shows the results of the same analyses for those under the age of 65 only. Very few respondent characteristics had across the board significance in the full sample. The exceptions were those retirees who had coordinated retirements with their spouses ${ }^{22}$ and females with self-reported poor health (defined previously). ${ }^{23}$ In both cases, having that characteristic significantly reduces the likelihood that one will increase his or her level of work regardless of the retirement identifier, the analysis method, the unretirement definition or sample restrictions based on age. The age of the respondent when first identified as retired tends to have a negative impact (as one would expect) on unretirement but it is not significant in many cases for the full sample. In the under-65 sample, the results are even more surprising. Though the age of the respondent at the retirement wave is significant for every specification, the sign of the impact is negative in probit analyses but positive in survival time analyses. The reason for this counter-intuitive finding in the survival time analysis is not clear.

\footnotetext{
${ }^{22}$ For the purposes of this study, "coordinated retirement" means that the respondents spouse is also retired at the time or interest (at retirement or in the previous wave depending on the analysis type), not that the couple retired at the same time.

${ }^{23}$ Men with self-rated poor health did not have a significantly lower rate of unretirement and, in fact, in some cases this characteristic is associated with a higher rate of reverse retiring when using the RAND labor force identifier.
} 
Gender and marital characteristics do not have consistent significance across specifications. For these characteristics, the excluded group is single females. Being a single male is associated with a lower unretirement rate (significantly for the under-65 sample) while married men have significantly higher unretirement probabilities and hazard ratios when using a self-reported retirement identifier, but the impacts are generally not significant with the RAND labor force status identifier. Married females do not have significantly different outcomes than their single counterparts in most analyses’ specifications with the exception of some probit specifications with a full retirement only definition. Those respondents whose spouse self-rates his or her health as poor or fair tend to not have significantly different influence on unretirement when using a directional definition of unretirement. For the full-retirement only definition of retirement, spouse's health has a significantly positive value for female respondents and a significantly negative effect on unretirement for males when using either retirement indicator in the probit analysis for the full sample. This significance is not present in the results for either gender in the survival time analysis. For respondents under 65 years of age, the values show the same coefficient sign pattern but are only significant for the self-reported retirement indicator and the "full-retirement only" definition of unretirement when using a probit analysis.

Race, region and educational attainment show limited relationships to future unretirement in this analysis. For the full sample, identifying oneself as black indicates a significantly higher likelihood of unretiring for all specifications other than those based on the RAND derived labor force status. This significant difference is not present in the under-65 sample except in one survival time specification. Being of "other race” or self- 
identifying as Hispanic leads to no significant differences from those identifying themselves as white in almost all cases. Surprisingly, educational attainment does not appear to play a significant role in post retirement changes in work level. In some specifications using the labor force status retirement indicator, those who have not attained at least a high school diploma are significantly more likely to unretire than those with a high school diploma for the full sample but are not significant for the under-65 sample. Attaining education above a high school diploma does not make a significant difference in unretirement rates in any specification on either sample. Regional differences are also minimal. Being from the Midwest Census Region appears to be the only region that is consistently significantly different from the South Region though only for survival time analyses.

In the following discussion and tables focusing on other respondent characteristics, the results for demographic, health, and wealth variables are suppressed though the tables indicate whether they have been included or not. With only a few exceptions, the significance and sign of the coefficients do not change with additional variables.

Tables 9 and 10 show the results following the introduction of the health insurance characteristics, which are of the most interest in this study. A control for whether a respondent receives a pension is also added. ${ }^{24}$ As discussed previously, this study separates respondents into four health insurance categories based on their source, if any, for coverage. Provision from a previous or current employer, a trade union, a

\footnotetext{
${ }^{24}$ Not surprisingly, receiving a pension payment at retirement or in the previous wave had a negative impact on unretirement probabilities and hazard ratio where significant different from zero with $95 \%$ confidence. It was significant in about half of the specifications under either the probit or survival time methodology.
} 
spouse's employer, or through a government program where the respondent does not pay the full cost is used as the control group. The non-control groups are those without any health insurance, those who purchase their health insurance directly from a private provider, and those who have current or former employer-provided health insurance but pay the full cost (i.e. it is not subsidized by the employer). The results for those without any form of health insurance are stark. In the probit analyses, the marginal impact on the probability of unretiring (evaluated at the mean) associated with changing from having subsidized health insurance at retirement to having no health insurance at retirement ranges from $8 \%$ to $13 \%$ in the full sample and from $8 \%$ to $17 \%$ in the over- 65 sample and is everywhere significant. ${ }^{25}$ The results are even stronger when using a survival time analysis. Individuals without health insurance in the previous wave are consistently twice as likely to unretire as those with subsidized insurance (everywhere significant at the $1 \%$ level for all specifications and both samples). Though the results under both the probit and the survival time analysis are strongly positive, the dramatically larger magnitudes of the survival time hazard ratios than the naïvely derived probability ratios ${ }^{26}$ show the significant underestimation of the importance of having some form of health insurance when limiting an analysis to only characteristics at the retirement wave.

The same kind of strong results are not seen when considering the purchase of private insurance. Those who purchase their own health insurance through a private provider do not have a significantly higher probability of unretiring or hazard rate than

\footnotetext{
${ }^{25}$ With the exception of the specification that uses the labor force indicator and does not control for demographic characteristics

${ }^{26}$ Values of the naïve probability ratio range from 1.3 to 1.7.
} 
those who have subsidized health insurance in almost all specifications. ${ }^{27}$ The likely reason for this is that two very different groups purchase the very costly private insurance and they have dramatically different unretirement tendencies. One group would be those who can easily afford private insurance and are very unlikely to unretire. The second group is those who are either very risk averse or are at high risk of accruing high medical bills and thus are not willing to go without insurance. Respondents in this group are more likely to unretire either to qualify for employer-provided health insurance or to earn extra income to afford their high premiums.

The case of full cost employer provided health insurance further exemplifies the advantages of the survival time model over a simple probit analysis. When looking at the probit specifications, the results for this indicator are almost everywhere insignificant. Conversely, the hazard ratios from the survival time analysis are almost everywhere significant and show $70 \%$ increases in the hazard rate when receiving unsubsidized employer provided health insurance compared to those receiving subsidized insurance in the full sample. In the under-65 sample, increases in the hazard ratios are lower for all specifications, averaging around $40 \%$, and the ratio is insignificant for the specification identified by self-reports of retirement with unretirement defined by the full-retirement only definition.

In Tables 11 and 12, a number of "shocks" are introduced. "Shock" is something of a misnomer as some of these occurances may be anticipated (such as decreases in wealth or increase in household size) but may also be surprises to the respondent. It is assumed that changes to health and medical expenses are not anticipated. As discussed

\footnotetext{
${ }^{27}$ The exceptions being the probit analyses using the self-reported retirement indicator and a full-retirement only definition for the full sample
} 
previously, shocks in the probit analysis represent changes from the retirement wave to the following wave and in the survival time analysis as changes from the previous wave and the wave prior. The addition of these shocks in the specifications had no impact on the sign and significance of almost all of our health insurance indicators discussed above.

Dramatic changes in wealth ${ }^{28}$ are associated with increases in the probability of unretiring in probit analyses for both the full and under-65 samples. Specifically, wealth shocks are significant for the RAND derived labor force status identified retirement specifications but not those identified by self-reported retirement status. Under a survival time specification with the full sample, wealth drops have everywhere significantly positive associations to unretirement with magnitudes ranging from $20 \%$ to $34 \%$ higher hazard rates when this shock occurs. The results are similar in magnitude for the under65 sample but the significance level declines in the self-reported retirement identified specifications because of larger standard errors (due to the smaller samples). These results hold true whether wealth at retirement is controlled for or not. Declines in health do not have any significant impact on unretirement probabilities and hazard rates even when self-reported poor health are not controlled for. The exception is for the full sample when retirement is identified by the labor force status value and changes are evaluated between the retirement wave and the following wave. In this case, health shocks are associated with significantly negative effects on unretirement probabilities. Similarly, increases in out-of-pocket medical expenses of fifty percent or more and at least $\$ 2,000$ (inflation adjusted) are not associated with changes in unretirement rates in almost all

\footnotetext{
${ }^{28}$ Here defined as a drop in inflation adjusted wealth of at least fifty percent between waves that is at least $\$ 10,000$
} 
specifications. ${ }^{29}$ Increases in household size are only associated with increased unretirement rates when using probit analyses while the same change in the previous wave are not significant under any specification of the survival time analyses.

In the final tables, Tables 13 and 14, this study addresses the previous work on expectations through the HRS survey question asking respondents whether they "plan to do paid work in retirement" and look at how the inclusion of this control affects the significance of insurance sources on unretirement. Because this question was only asked in the first HRS wave in 1992, the sample is limited to the Initial HRS cohort only. The expectation of working in retirement has a significant and sizeable impact on both the probability and hazard rate of unretirement under all specifications and both the full Initial HRS cohort and the under-65 sub-sample. The marginal impact on the probability of unretiring is between $10 \%$ and $12 \%$ for the Initial HRS cohort and between $6 \%$ and 8\% for the under-65 sample. The hazard ratio for this expectation ranged from 1.4 to 1.9 over both samples.

The addition of the future employment expectations to this study's analyses has a small impact on the previously discussed health insurance characteristics. For those who do not have any form of health insurance, the size of the marginal impacts and hazard ratios are uniformly reduced but only fail to continue to be significant in the probit analyses where the full-retirement definition of unretirement was used. There is no change in the across the board insignificance for those who purchase their own private insurance. Unsubsidized employer provided health insurance continues to have an insignificant impact on unretirement rates when a probit analysis is done. The

\footnotetext{
${ }^{29}$ It should be noted that the health insurance sources are controlled for and therefore the variability of expenses may be related to that source and whether one has insurance at all.
} 
significance for the survival time analysis of this source of health insurance does not change when retirement work expecations are included and even has many hazard ratios increase in magnitude. ${ }^{30}$

Like earlier tables, Table $\mathrm{X}$ highlights the differences in the relative significance of some variables between the static probit analysis and the time-variant survival time analysis. If one where to solely look at the probit results with the full Initial HRS cohort, the respondent's expectation of working in retirement would appear to be consistently more important than having health insurance for the decision to unretire. When respondents' health insurance access is allowed to vary with time for the full sample in the survival time analysis, this relationship is reversed. When looking at the results for the full-sample, both having no insurance and having unsubsidized employer provided health insurance have larger hazard ratios than that for the work expectation in all cases except the case where the labor force status is used to define retirement with a full retirement only definition of unretirement. This analysis comparison does not hold true when restricting our sample to only those younger than 65 years of age. In that case, the marginal probability changes for those with no health insurance are dramatically larger than the margin probability changes for expecting to work in retirement (though the significance of the prior is not consistent). This relationship is logical since those who are not old enough to qualify for Medicare should be most influenced by insurance considerations.

\section{Conclusion:}

\footnotetext{
${ }^{30}$ The hazard ratio of those with unsubsidized employer provided health insurance to those with subsidized health insurance continues to be insignificant when a full retirement only definition of unretirement for those in the under-65 subsample when using a survival time analysis.
} 
Through the use of survival time analysis, this paper has shown that health insurance plays a significant role in unretirement decisions. This role is underestimated when a static probit analysis is used alone. The results hold up for a number of different retirement identifiers that are based both on self-reports of retirement and actual work levels. The results are also robust to various definitions of retirement prompted by the difficult question of how to classify partial retirements. The importance of health insurance provision in a retiree's decision also remains significant when other "shocks" and the prospect of planned unretirement are introduced.

This study supports the finding of past studies that a significant number of retirees return to work after a period of retirement, irregardless of how one defines retirement. As such, more work needs to be done to refine previous retirement models so that they can account for the real choice that retirees make to return to work or develop new models that can explain this phenomenon. Any model will need to include both the motivations behind anticipating a future return to work and the role that health insurance plays in labor force decisions. The latter has been examined previously in regard to leaving the work force and this study has shown its significance in choices to leave full or partial retirement. One policy extension for such a model would be the effects of legislation to offer 62 year-olds the ability to buy into Medicare (which they do not currently have). The implications of this type of extension of benefits have been studied in the context of the choice to retire, but not in the area of a retiree's decision to return to work. 


\section{References:}

Benitez-Silva, Hugo and Frank Heiland (2003), "Micro Determinants of Labor Force Status among Older Americans,” Stony Brook, NY: State University of New York at Stony Brook.

Berkovec, James and Steven Stern (1991), “Job exit behavior of older men”, Econometrica 59(1): 189-210.

Blau, David and Donna Gilleskie (2001), "Retiree Health Insurance and the Labor Force Behavior of Older Men in the 1990s”, Review of Economics and Statistics 83(1): 64-80.

Fronstin, Paul (2005), “The impact of the erosion of retiree health benefits on workers and retirees”, http://www.ebri.org/ibpdfs/0305ib.pdf.

General Accounting Office (1996), "Private Health Insurance: Millions Relying on Individual Market Face Cost and Coverage Tradeoffs", Report to the Committee on Labor and Human Resources, U.S. Senate, November 1996.

General Accounting Office (1998), “Private Health Insurance: Declining Employer Coverage May Affect Access for 55- to 64-year-olds”, GAO/HEHS-98-133.

General Accounting Office (1999), "Private Health Insurance: Progress and Challenges in Implementing 1995 Federal Standards”, GAO/HEHS- 99-100.

Gruber, Jonathan and Brigitte Madrian (1995), "Health Insurance Availability and the Retirement Decision”, American Economic Review 85(4): 938-48.

Gustman, Alan and Thomas Steinmeier (1986), “A Structural Retirement Model”, Econometrica 54 (3): 555-584.

Gustman, Alan and Thomas Steinmeier (1994), "Employer-Provided Health Insurance and Retirement Behavior”, Industrial and Labor Relations Review 48(1):124-40.

Hogg, Robert and Allen Craig (1995), Introduction to Statistical Inference $5^{\text {th }}$ Edition, Prentice Hall, New Jersey.

Johnson, Richard W, Amy Davidoff, and Kevin Perese (2003), "Health Insurance Costs and Early Retirement Decisions”, Industrial and Labor Relations Review 56: 716.

Karoly, Lynn and Jeannette Rogowski (1994), “The Effect of Access to Post-Retirement Health Insurance on the Decision to Retire Early”, Industrial and Labor Relations Review 48(1): 103-23. 
Kaiser Family Foundation and Health Research and Education Trust (2006), "Employer Health Benefits: 2006 Annual Survey Summary of Findings”, www.kff.org/insurance/7527/index.cfm.

Lumsdaine, Robin and Olivia Mitchell (1999), “New Developments in the Economic Analysis of Retirement”, Handbook of Labor Economics, Vol. 3, Eds. O. Ashenfelter and D. Card: 3261-3307.

Lumsdaine, Robin, James Stock and David Wise (1992), "Pension Plan Provisions and Retirement: Men and Women, Medicare and Models”, NBER Working Paper No. 4201.

Madrian, Brigitte and Nancy Beaulieu (1998), “Does Medicare Eligibility Affect Retirement?” Inquiries in the Economics of Aging, Ed. David Wise. Chicago University Press: 109-131.

Maestas, Nicole (2004), "Back to Work: Expectations and Realizations of Work after Retirement” RAND Working Paper.

Rogowski, Jeannette and Lynn Karoly (2000), “Health Insurance and Retirement Behavior: Evidence from the Health and Retirement Survey”, Journal of Health Economics 19(4): 529-39.

Ruhm, Christopher (1990), "Bridge Jobs and Partial Retirement,” Journal of Labor Economics 8(4): 482-501.

Rust, John and Christopher Phelan (1997), "How Social Security and Medicare Affect Retirement Behavior in a World of Incomplete Markets”, Econometrica 65(4): 781-831.

Stock, James and David Wise (1990), "Pensions, the option value of work and retirement”, Econometrica 58 (5): 1151-1180.

Wooldridge, Jeffrey (2002), Econometric Analysis of Cross Section and Panel Data, The MIT Press, Cambridge, Massachusetts. 
Table 1 : Retirement Reports as Defined by the Two Primary Variables Cells contain the number of reports for each pair of responses

\begin{tabular}{|l|c|c|c|c|}
\hline & \multicolumn{4}{|c|}{ Rand Derived Labor Force Status } \\
\hline $\begin{array}{l}\text { Self-Report of Retirement } \\
\text { Status }\end{array}$ & Not Retired & $\begin{array}{c}\text { Full } \\
\text { Retirement }\end{array}$ & $\begin{array}{c}\text { Partial } \\
\text { Retirement }\end{array}$ & Missing \\
\hline Not Retired & 27,210 & 284 & 110 & 28 \\
\hline Full Retirement & 89 & 8,510 & 497 & 0 \\
\hline Partial Retirement & 708 & 993 & 2,620 & 0 \\
\hline Missing & 2,209 & 333 & 73 & 33 \\
\hline
\end{tabular}


Table 2: Identifying Potential Sample Selection Bias

\begin{tabular}{|l|c|c|c|}
\hline \multicolumn{1}{|c|}{$\begin{array}{c}\text { Evaluated at the First } \\
\text { Observed Wave }\end{array}$} & $\begin{array}{c}\text { Did Not } \\
\text { Observed in } \\
\text { all Waves (1) }\end{array}$ & $\begin{array}{c}\text { it least } \\
\text { One Wave (1) }\end{array}$ & t-value (2) \\
\hline Number of Respondents & 8346 & 3111 & \\
\hline Age in Years & 54.25 & 54.32 & 0.91 \\
\hline Male & $42.8 \%$ & $45.3 \%$ & 2.42 \\
\hline Married & $79.7 \%$ & $78.4 \%$ & 1.53 \\
\hline Currently Working & $73.8 \%$ & $72.1 \%$ & 1.81 \\
\hline $\begin{array}{l}\text { Self-rated Health (1-excellent, } \\
\text { 5-poor) }\end{array}$ & 2.43 & 2.54 & 4.71 \\
\hline R Reports Being White & $82.0 \%$ & $76.0 \%$ & 7.23 \\
\hline R Reports Being "Other Race" & $14.5 \%$ & $18.9 \%$ & 5.66 \\
\hline R Reports Being Black & $3.4 \%$ & $5.1 \%$ & 4.19 \\
\hline R Reports Being Hispanic & $7.8 \%$ & $12.4 \%$ & 7.74 \\
\hline R from North Census Division & $16.9 \%$ & $18.9 \%$ & 2.45 \\
\hline R from South Census Region & $25.7 \%$ & $22.0 \%$ & 4.07 \\
\hline $\begin{array}{l}\text { R from Midwest Census } \\
\text { Division }\end{array}$ & $40.7 \%$ & $44.5 \%$ & 3.60 \\
\hline R from West Census Division & $16.6 \%$ & $14.6 \%$ & 2.63 \\
\hline $\begin{array}{l}\text { R has less than High School } \\
\text { Diploma or GED }\end{array}$ & $20.9 \%$ & $27.3 \%$ & 7.37 \\
\hline R has High School Diploma & $37.6 \%$ & $37.1 \%$ & 0.51 \\
\hline R has Some College but No & $21.0 \%$ & $20.0 \%$ & 1.18 \\
\hline Regree has College Degree or More & $20.5 \%$ & $15.6 \%$ & 5.98 \\
\hline
\end{tabular}

(1) Included are age eligible, active in the first eligible wave for their cohort and not observed as dying in any wave

(2) The hypothesis that the two means are equal can be rejected with $95 \%$ confidence if the t-value is over 1.96 
Table 3: Sample Restrictions and the Size of the Final Samples

Cells contain the number of Respondents remaining in the sample after each restriction

\begin{tabular}{|c|c|c|c|c|c|c|}
\hline & \multicolumn{3}{|c|}{ Self-reported Retirement Status } & \multicolumn{3}{|c|}{ Rand Labor Force Status } \\
\hline & Initial HRS & $\begin{array}{c}\text { War } \\
\text { Babies }\end{array}$ & Total & Initial HRS & $\begin{array}{c}\text { War } \\
\text { Babies }\end{array}$ & Total \\
\hline HRS respondents & 13367 & 2694 & 16061 & 13367 & 2694 & 16061 \\
\hline $\begin{array}{l}\text { Age Eligible for either cohort: Born } \\
\text { between } 1931 \text { and } 1947 \text { (1) }\end{array}$ & 11459 & 2121 & 13580 & 11459 & 2121 & 13580 \\
\hline Alive in all Survey Years & 9953 & 2048 & 12001 & 9953 & 2048 & 12001 \\
\hline $\begin{array}{l}\text { Observed in all } 7 \text { waves for Initial HRS } \\
\text { or all } 4 \text { waves for War Babies }\end{array}$ & 6703 & 1643 & 8346 & 6703 & 1643 & 8346 \\
\hline Working in First Observed Wave & 4531 & 1232 & 5763 & 4531 & 1232 & 5763 \\
\hline $\begin{array}{l}\text { Must not have missing retirement } \\
\text { variables }\end{array}$ & 3944 & 1065 & 5009 & 4531 & 1232 & 5763 \\
\hline \multicolumn{7}{|c|}{ Retirement Definition Specific Final Samples: } \\
\hline $\begin{array}{l}\text { Observed for at least } 1 \text { Wave Post- } \\
\text { Retirement (Directional Definition) }\end{array}$ & 2577 & 168 & 2745 & 2856 & 174 & 3030 \\
\hline $\begin{array}{l}\text { Observed for at least } 1 \text { Wave Post- } \\
\text { Retirement while under } 65 \text { (Directional } \\
\text { Definition) }\end{array}$ & 1590 & 165 & 1755 & 1715 & 169 & 1884 \\
\hline $\begin{array}{l}\text { Observed for at least } 1 \text { Wave Post- } \\
\text { Retirement (Full Retirement Only } \\
\text { Definition) }\end{array}$ & 1906 & 87 & 1993 & 2313 & 123 & 2436 \\
\hline $\begin{array}{l}\text { Observed for at least } 1 \text { Wave Post- } \\
\text { Retirement while under } 65 \text { (Full } \\
\text { Retirement Only Definition) }\end{array}$ & 1034 & 86 & 1120 & 1298 & 119 & 1417 \\
\hline
\end{tabular}

(1) 1931 to 1941 for Initial cohort and 1942 to 1947 for WB 
Table 4: Unretirement Portions by Sample Specification

\begin{tabular}{|c|c|c|c|c|}
\hline \multirow{2}{*}{$\begin{array}{c}\text { Portion of the } \\
\text { Sample ever } \\
\text { Unretiring }\end{array}$} & \multicolumn{2}{|c|}{ Self-reported Retirement } & \multicolumn{2}{|c|}{$\begin{array}{c}\text { Rand Labor Force } \\
\text { Status }\end{array}$} \\
\hline & $\begin{array}{l}\text { Directional } \\
\text { Definition }\end{array}$ & \begin{tabular}{|c|} 
Full- \\
Retirement \\
Only \\
\end{tabular} & $\begin{array}{l}\text { Directional } \\
\text { Definition }\end{array}$ & $\begin{array}{l}\text { Full- } \\
\text { Retirement } \\
\text { Only }\end{array}$ \\
\hline Full-Sample (1) & $30.6 \%$ & $25.1 \%$ & $29.4 \%$ & $25.0 \%$ \\
\hline Under-65 & $27.4 \%$ & $23.2 \%$ & $23.3 \%$ & $20.4 \%$ \\
\hline Original HRS & $30.8 \%$ & $25.0 \%$ & $29.6 \%$ & $25.0 \%$ \\
\hline War Babies & $26.8 \%$ & $27.6 \%$ & $27.0 \%$ & $25.2 \%$ \\
\hline
\end{tabular}

(1) Individuals in all samples are observed for at least one wave following retirement 
Table 5: Differences in Means for Demographic, Health, and Wealth Characteristics

\begin{tabular}{|c|c|c|c|c|c|c|}
\hline \multirow[b]{2}{*}{$\begin{array}{l}\text { All Values at Retirement } \\
\text { Wave }\end{array}$} & \multicolumn{3}{|c|}{$\begin{array}{c}\text { Self-reported Retirement Status } \\
\text { Directional Definition } \\
\text { Full Sample } \\
\end{array}$} & \multicolumn{3}{|c|}{$\begin{array}{c}\text { Rand Labor Force Status } \\
\text { Directional Definition } \\
\text { Full Sample } \\
\end{array}$} \\
\hline & $\begin{array}{c}\text { Permanent } \\
\text { Retirees }\end{array}$ & \begin{tabular}{|c|} 
Future \\
Unretirees
\end{tabular} & t-value (1) & $\begin{array}{l}\text { Permanent } \\
\text { Retirees }\end{array}$ & \begin{tabular}{|c|} 
Future \\
Unretirees
\end{tabular} & t-value \\
\hline Age in Years & 61.13 & 60.03 & 7.15 & 61.20 & 60.43 & 5.11 \\
\hline Male & $43.8 \%$ & $47.3 \%$ & 1.73 & $46.0 \%$ & $50.4 \%$ & 2.18 \\
\hline $\begin{array}{l}\text { Married or "Partnered", } \\
\text { includes Absent Spouse }\end{array}$ & $74.9 \%$ & $75.3 \%$ & 0.23 & $76.2 \%$ & $77.6 \%$ & 0.83 \\
\hline Married and Male & $36.2 \%$ & $41.2 \%$ & 2.47 & $39.3 \%$ & $43.5 \%$ & 2.17 \\
\hline $\begin{array}{l}\text { R \& SP retired at R's } \\
\text { Retirement Wave }\end{array}$ & $39.2 \%$ & $32.1 \%$ & 3.6 & $39.3 \%$ & $35.2 \%$ & 2.08 \\
\hline $\begin{array}{l}\text { Self-rated 'Poor' or 'Fair' } \\
\text { Health }\end{array}$ & $22.2 \%$ & $15.9 \%$ & 3.79 & $24.0 \%$ & $15.3 \%$ & 5.39 \\
\hline $\begin{array}{l}\text { Spouse Self-rated 'Poor' or } \\
\text { 'Fair' Health }\end{array}$ & $13.3 \%$ & $14.2 \%$ & 0.62 & $15.1 \%$ & $13.8 \%$ & 0.93 \\
\hline $\begin{array}{l}\text { Total Wealth (in 100,000s) } \\
\text { in } 2000 \text { \$'s }\end{array}$ & 3.93 & 3.58 & 1.23 & 3.71 & 4.07 & 1.34 \\
\hline R Reports Being White & $84.5 \%$ & $80.8 \%$ & 2.37 & $82.8 \%$ & $82.4 \%$ & 0.25 \\
\hline $\begin{array}{l}\text { R Reports Being "Other } \\
\text { Race" }\end{array}$ & $2.0 \%$ & $3.3 \%$ & 2.02 & $2.6 \%$ & $2.7 \%$ & 0.19 \\
\hline R Reports Being Black & $13.5 \%$ & $15.9 \%$ & 1.64 & $14.7 \%$ & $14.9 \%$ & 0.17 \\
\hline R Reports Being Hispanic & $5.2 \%$ & $6.4 \%$ & 1.25 & $6.1 \%$ & $5.8 \%$ & 0.25 \\
\hline $\begin{array}{l}\text { R has less than High } \\
\text { School Diploma or GED }\end{array}$ & $17.3 \%$ & $17.6 \%$ & 0.24 & $20.3 \%$ & $15.9 \%$ & 2.78 \\
\hline R has High School Diploma & $39.8 \%$ & $38.7 \%$ & 0.54 & $39.2 \%$ & $39.7 \%$ & 0.28 \\
\hline $\begin{array}{l}\mathrm{R} \text { has Some College but No } \\
\text { Degree }\end{array}$ & $20.7 \%$ & $21.2 \%$ & 0.32 & $20.2 \%$ & $21.9 \%$ & 1.02 \\
\hline $\begin{array}{l}\mathrm{R} \text { has College Degree or } \\
\text { More }\end{array}$ & $22.2 \%$ & $22.4 \%$ & 0.93 & $20.3 \%$ & $22.4 \%$ & 1.33 \\
\hline
\end{tabular}

(1) The hypothesis that the two means are equal can be rejected with 95\% confidence if the t-value is over 1.96 
Table 6: Differences in Means for Health Insurance Sources, Shocks, and 1992 Expectations

\begin{tabular}{|c|c|c|c|c|c|c|c|c|c|c|c|c|}
\hline & \multicolumn{6}{|c|}{$\begin{array}{l}\text { Self-reported Retirement Status } \\
\text { Directional Definition }\end{array}$} & \multicolumn{6}{|c|}{$\begin{array}{l}\text { Rand Labor Force Status } \\
\text { Directional Definition }\end{array}$} \\
\hline & \multicolumn{3}{|c|}{$\begin{array}{l}\text { At Retirement or the Change } \\
\text { between Retirement Wave and } \\
\text { the Next }\end{array}$} & \multicolumn{3}{|c|}{$\begin{array}{l}\text { Previous Wave Value or the } \\
\text { Change between the Previous } \\
\text { Wave and the One Prior }\end{array}$} & \multicolumn{3}{|c|}{$\begin{array}{c}\text { At Retirement or the Change } \\
\text { between Retirement Wave and } \\
\text { the Next }\end{array}$} & \multicolumn{3}{|c|}{$\begin{array}{l}\text { Previous Wave Value or the } \\
\text { Change between the Previous } \\
\text { Wave and the One Prior }\end{array}$} \\
\hline & $\begin{array}{c}\text { Permanent } \\
\text { Retirees }\end{array}$ & \begin{tabular}{|c|} 
Future \\
Unretirees \\
\end{tabular} & $\begin{array}{c}\mathrm{t} \text {-value } \\
\text { (1) }\end{array}$ & \begin{tabular}{c|} 
Permanent \\
Retirees
\end{tabular} & $\begin{array}{c}\text { Future } \\
\text { Unretirees }\end{array}$ & t-value & $\begin{array}{c}\text { Permanent } \\
\text { Retirees }\end{array}$ & $\begin{array}{c}\text { Future } \\
\text { Unretirees }\end{array}$ & t-value & \begin{tabular}{c|} 
Permanent \\
Retirees
\end{tabular} & \begin{tabular}{c|} 
Future \\
Unretirees
\end{tabular} & t-value \\
\hline Respondent (R) Has No Health Insurance & $8.3 \%$ & $11.8 \%$ & 2.86 & $5.4 \%$ & $10.0 \%$ & 5.22 & $8.8 \%$ & $12.3 \%$ & 3.00 & $5.8 \%$ & $9.6 \%$ & 4.27 \\
\hline R Buys Private Health Insurance & $7.8 \%$ & $11.1 \%$ & 2.83 & $6.5 \%$ & $10.8 \%$ & 4.54 & $7.6 \%$ & $10.8 \%$ & 2.88 & $6.3 \%$ & $9.9 \%$ & 3.98 \\
\hline $\begin{array}{l}\text { Employer Provided Health Insurance but R Pays } \\
\text { Full Cost (Unsubsidized) } \\
\end{array}$ & $21.2 \%$ & $24.9 \%$ & 2.15 & $15.1 \%$ & $22.6 \%$ & 5.45 & $20.8 \%$ & $23.7 \%$ & 1.78 & $14.8 \%$ & $21.4 \%$ & 5.06 \\
\hline R Receives Pension & $36.1 \%$ & $31.3 \%$ & 2.41 & $42.4 \%$ & $37.8 \%$ & 2.5 & $36.6 \%$ & $32.8 \%$ & 1.99 & $42.5 \%$ & $36.5 \%$ & 3.37 \\
\hline $\begin{array}{l}\text { Total Wealth Drops more than } 50 \% \text { \& more than } \\
\$ 10000 \text { between Waves }\end{array}$ & $10.7 \%$ & $12.8 \%$ & 1.6 & $10.3 \%$ & $13.7 \%$ & 3.01 & $10.7 \%$ & $14.1 \%$ & 2.68 & $10.7 \%$ & $13.7 \%$ & 2.66 \\
\hline $\begin{array}{l}\text { R's Health Declines by } 2 \text { Levels or more between } \\
\text { Waves }\end{array}$ & $3.3 \%$ & $3.9 \%$ & 0.89 & $4.8 \%$ & $3.9 \%$ & 1.06 & $4.1 \%$ & $2.5 \%$ & 2.21 & $5.4 \%$ & $4.0 \%$ & 1.69 \\
\hline R's Household Size Increases between Waves & $7.9 \%$ & $11.2 \%$ & 2.78 & $8.5 \%$ & $8.6 \%$ & 0.12 & $8.1 \%$ & $10.8 \%$ & 2.37 & $8.4 \%$ & $9.0 \%$ & 0.59 \\
\hline $\begin{array}{l}\text { Out-of-Pocket Medical Expenses increase by more } \\
\text { than } 50 \% \text { \& over } \$ 2,000 \text { between Waves }\end{array}$ & $15.7 \%$ & $13.6 \%$ & 1.42 & $15.2 \%$ & $13.9 \%$ & 0.97 & $15.9 \%$ & $14.3 \%$ & 1.14 & $15.3 \%$ & $16.3 \%$ & 0.77 \\
\hline $\begin{array}{l}\text { Respondent Plans to do Paid Work in Retirement } \\
\text { (asked in Wave } 1 \text { only) }\end{array}$ & $70.0 \%$ & $79.0 \%$ & 4.68 & $69.2 \%$ & $79.0 \%$ & 5.57 & $69.5 \%$ & $80.6 \%$ & 5.86 & $68.4 \%$ & $80.6 \%$ & 6.97 \\
\hline
\end{tabular}

(1) The hypothesis that the two means are equal can be rejected with $95 \%$ confidence if the t-value is over 1.96 
Table 7: Probit and Survival Analysis of Unretirement Using Demographic and Health Controls

\begin{tabular}{|c|c|c|c|c|c|c|c|c|}
\hline \multirow{3}{*}{ Full-Sample } & \multicolumn{2}{|c|}{$\begin{array}{c}\text { Self-reported } \\
\text { Retirement Status } \\
\text { Directional Definition }\end{array}$} & \multicolumn{2}{|c|}{$\begin{array}{l}\text { Rand Labor Force } \\
\text { Status } \\
\text { Directional Definition }\end{array}$} & \multicolumn{2}{|c|}{$\begin{array}{c}\text { Self-reported } \\
\text { Retirement Status } \\
\text { Full-retirement Only } \\
\text { Definition }\end{array}$} & \multicolumn{2}{|c|}{$\begin{array}{l}\text { Rand Labor Force } \\
\text { Status } \\
\text { Full-retirement Only } \\
\text { Definition }\end{array}$} \\
\hline & Probit (1) & $\begin{array}{l}\text { Survival } \\
\text { Time }\end{array}$ & Probit & $\begin{array}{l}\text { Survival } \\
\text { Time }\end{array}$ & Probit & $\begin{array}{l}\text { Survival } \\
\text { Time }\end{array}$ & Probit & $\begin{array}{l}\text { Survival } \\
\text { Time }\end{array}$ \\
\hline & $\begin{array}{c}\text { Marginal } \\
\text { Impact }\end{array}$ & $\begin{array}{c}\text { Hazard } \\
\text { Ratio }\end{array}$ & $\begin{array}{l}\text { Marginal } \\
\text { Impact }\end{array}$ & $\begin{array}{c}\text { Hazard } \\
\text { Ratio }\end{array}$ & $\begin{array}{l}\text { Marginal } \\
\text { Impact }\end{array}$ & $\begin{array}{c}\text { Hazard } \\
\text { Ratio }\end{array}$ & $\begin{array}{l}\text { Marginal } \\
\text { Impact }\end{array}$ & $\begin{array}{c}\text { Hazard } \\
\text { Ratio }\end{array}$ \\
\hline Age in Years at Retirement Wave & $\begin{array}{c}-0.013^{* *} \\
{[0.003]}\end{array}$ & $\begin{array}{l}0.971^{\star \star} \\
{[0.010]} \\
\end{array}$ & $\begin{array}{c}-0.007^{\star \star} \\
{[0.002]}\end{array}$ & $\begin{array}{c}0.998 \\
{[0.011]} \\
\end{array}$ & $\begin{array}{l}-0.007^{*} \\
{[0.003]} \\
\end{array}$ & $\begin{array}{c}1.003 \\
{[0.015]} \\
\end{array}$ & $\begin{array}{c}-0.005 \\
{[0.003]} \\
\end{array}$ & $\begin{array}{c}1.005 \\
{[0.013]} \\
\end{array}$ \\
\hline Male & $\begin{array}{l}-0.084^{\star} \\
{[0.041]}\end{array}$ & $\begin{array}{c}0.727 \\
{[0.127]}\end{array}$ & $\begin{array}{c}-0.016 \\
{[0.040]}\end{array}$ & $\begin{array}{c}0.96 \\
{[0.159]}\end{array}$ & $\begin{array}{l}-0.077 \\
{[0.044]}\end{array}$ & $\begin{array}{c}0.668 \\
{[0.152]}\end{array}$ & $\begin{array}{l}-0.014 \\
{[0.041]}\end{array}$ & $\begin{array}{c}0.869 \\
{[0.173]}\end{array}$ \\
\hline Married or "Partnered", includes Absent Spouse & $\begin{array}{c}-0.047 \\
{[0.032]}\end{array}$ & $\begin{array}{c}1.106 \\
{[0.130]}\end{array}$ & $\begin{array}{l}-0.006 \\
{[0.030]}\end{array}$ & $\begin{array}{c}1.235 \\
{[0.150]}\end{array}$ & $\begin{array}{l}-0.070^{\star} \\
{[0.035]}\end{array}$ & $\begin{array}{c}0.9 \\
{[0.131]}\end{array}$ & $\begin{array}{l}-0.013 \\
{[0.031]}\end{array}$ & $\begin{array}{c}1.024 \\
{[0.145]}\end{array}$ \\
\hline Married and Male & $\begin{array}{l}0.148^{\star \star} \\
{[0.049]}\end{array}$ & $\begin{array}{l}1.554^{\star} \\
{[0.305]}\end{array}$ & $\begin{array}{c}0.05 \\
{[0.045]}\end{array}$ & $\begin{array}{c}1.197 \\
{[0.224]}\end{array}$ & $\begin{array}{l}0.154^{\star *} \\
{[0.054]}\end{array}$ & $\begin{array}{l}1.966^{\star \star} \\
{[0.505]}\end{array}$ & $\begin{array}{c}0.065 \\
{[0.047]}\end{array}$ & $\begin{array}{c}1.543 \\
{[0.347]}\end{array}$ \\
\hline R \& SP retired at R's Retirement Wave & $\begin{array}{c}-0.065^{\star *} \\
{[0.021]}\end{array}$ & & $\begin{array}{l}-0.048^{*} \\
{[0.020]} \\
\end{array}$ & & $\begin{array}{c}-0.075^{\star \star} \\
{[0.023]} \\
\end{array}$ & & $\begin{array}{c}-0.072^{\star \star} \\
{[0.020]}\end{array}$ & \\
\hline R \& SP retired in Previous Wave & & $\begin{array}{l}0.521^{\star \star} \\
{[0.044]}\end{array}$ & & $\begin{array}{l}0.553^{\star \star} \\
{[0.044]}\end{array}$ & & $\begin{array}{l}0.583^{\star \star} \\
{[0.065]}\end{array}$ & & $\begin{array}{l}0.544^{\star \star} \\
{[0.055]}\end{array}$ \\
\hline $\begin{array}{l}\text { Total Wealth (in 100,000s) in } 2000 \text { \$'s at time of } \\
\text { Retirement }\end{array}$ & $\begin{array}{l}-0.001 \\
{[0.001]} \\
\end{array}$ & $\begin{array}{c}0.996 \\
{[0.007]}\end{array}$ & $\begin{array}{c}0.001 \\
{[0.001]}\end{array}$ & $\begin{array}{c}1.004 \\
{[0.005]}\end{array}$ & $\begin{array}{c}0.000 \\
{[0.002]} \\
\end{array}$ & $\begin{array}{c}1.000 \\
{[0.010]}\end{array}$ & $\begin{array}{c}0.001 \\
{[0.002]} \\
\end{array}$ & $\begin{array}{c}1.012 \\
{[0.008]} \\
\end{array}$ \\
\hline $\begin{array}{l}\text { Self-rated 'Poor' or 'Fair' Health at Retirement } \\
\text { Wave }\end{array}$ & $\begin{array}{c}-0.148^{* *} \\
{[0.026]}\end{array}$ & & $\begin{array}{l}-0.166^{\star \star} \\
{[0.025]}\end{array}$ & & $\begin{array}{l}-0.145^{\star *} \\
{[0.027]}\end{array}$ & & $\begin{array}{c}-0.164^{\star \star} \\
{[0.025]}\end{array}$ & \\
\hline Self-rated 'Poor' or 'Fair' Health at Previous Wave & & $\begin{array}{l}0.537^{\star \star} \\
{[0.074]}\end{array}$ & & $\begin{array}{l}0.489^{\star \star} \\
{[0.072]}\end{array}$ & & $\begin{array}{l}0.491^{\star \star} \\
{[0.087]}\end{array}$ & & $\begin{array}{l}0.407^{\star \star} \\
{[0.076]}\end{array}$ \\
\hline \begin{tabular}{|l|} 
Male \& Self-rated 'Poor' or 'Fair' Health at \\
Retirement Wave
\end{tabular} & $\begin{array}{c}0.101 \\
{[0.052]}\end{array}$ & & $\begin{array}{l}0.141^{\star \star} \\
{[0.049]}\end{array}$ & & $\begin{array}{c}0.106 \\
{[0.058]}\end{array}$ & & $\begin{array}{l}0.164^{\star \star} \\
{[0.054]}\end{array}$ & \\
\hline $\begin{array}{l}\text { Male \& Self-rated 'Poor' or 'Fair' Health at Previous } \\
\text { Wave }\end{array}$ & & $\begin{array}{c}1.223 \\
{[0.244]}\end{array}$ & & $\begin{array}{c}1.428 \\
{[0.279]}\end{array}$ & & $\begin{array}{c}1.198 \\
{[0.307]}\end{array}$ & & $\begin{array}{l}1.782^{*} \\
{[0.422]}\end{array}$ \\
\hline $\begin{array}{l}\text { Spouse Self-rated 'Poor' or 'Fair' Health at } \\
\text { Retirement Wave }\end{array}$ & $\begin{array}{c}0.078 \\
{[0.041]}\end{array}$ & & $\begin{array}{c}0.031 \\
{[0.037]}\end{array}$ & & $\begin{array}{l}0.120^{*} \\
{[0.048]}\end{array}$ & & $\begin{array}{l}0.091^{*} \\
{[0.041]}\end{array}$ & \\
\hline $\begin{array}{l}\text { Spouse Self-rated 'Poor' or 'Fair' Health at } \\
\text { Previous Wave }\end{array}$ & & $\begin{array}{c}1.081 \\
{[0.157]}\end{array}$ & & $\begin{array}{c}1.05 \\
{[0.150]}\end{array}$ & & $\begin{array}{c}1.172 \\
{[0.217]}\end{array}$ & & $\begin{array}{c}1.336 \\
{[0.219]}\end{array}$ \\
\hline $\begin{array}{l}\text { Male \& Spouse Self-rated 'Poor' or 'Fair' Health at } \\
\text { Retirement Wave }\end{array}$ & $\begin{array}{c}-0.063 \\
{[0.049]}\end{array}$ & & $\begin{array}{c}-0.04 \\
{[0.047]}\end{array}$ & & $\begin{array}{l}-0.111^{\star \star} \\
{[0.043]}\end{array}$ & & $\begin{array}{l}-0.106^{\star \star} \\
{[0.038]}\end{array}$ & \\
\hline $\begin{array}{l}\text { Male \& Spouse Self-rated 'Poor' or 'Fair' Health at } \\
\text { Previous Wave }\end{array}$ & & $\begin{array}{c}1.116 \\
{[0.230]}\end{array}$ & & $\begin{array}{c}0.951 \\
{[0.194]}\end{array}$ & & $\begin{array}{c}0.961 \\
{[0.254]}\end{array}$ & & $\begin{array}{c}0.72 \\
{[0.173]} \\
\end{array}$ \\
\hline R Reports Being "Other Race" & $\begin{array}{c}0.117 \\
{[0.065]}\end{array}$ & $\begin{array}{l}1.604^{*} \\
{[0.351]}\end{array}$ & $\begin{array}{c}0.032 \\
{[0.057]}\end{array}$ & $\begin{array}{c}1.3 \\
{[0.311]}\end{array}$ & $\begin{array}{c}0.05 \\
{[0.074]}\end{array}$ & $\begin{array}{c}1.275 \\
{[0.400]}\end{array}$ & $\begin{array}{l}-0.046 \\
{[0.056]}\end{array}$ & $\begin{array}{c}0.868 \\
{[0.283]} \\
\end{array}$ \\
\hline R Reports Being Black & $\begin{array}{l}0.062^{*} \\
{[0.029]} \\
\end{array}$ & $\begin{array}{l}1.376^{\star \star} \\
{[0.150]}\end{array}$ & $\begin{array}{c}0.044 \\
{[0.027]} \\
\end{array}$ & $\begin{array}{l}1.289^{\star} \\
{[0.140]}\end{array}$ & $\begin{array}{l}0.083^{\star} \\
{[0.033]}\end{array}$ & $\begin{array}{l}1.616^{\star \star} \\
{[0.217]}\end{array}$ & $\begin{array}{c}0.046 \\
{[0.028]}\end{array}$ & $\begin{array}{l}1.291^{*} \\
{[0.167]} \\
\end{array}$ \\
\hline R Reports Being Hispanic & $\begin{array}{c}0.066 \\
{[0.045]}\end{array}$ & $\begin{array}{c}1.273 \\
{[0.195]}\end{array}$ & $\begin{array}{c}0.049 \\
{[0.041]}\end{array}$ & $\begin{array}{c}1.175 \\
{[0.195]}\end{array}$ & $\begin{array}{c}0.049 \\
{[0.048]}\end{array}$ & $\begin{array}{c}1.347 \\
{[0.276]} \\
\end{array}$ & $\begin{array}{c}0.034 \\
{[0.042]}\end{array}$ & $\begin{array}{c}1.179 \\
{[0.242]} \\
\end{array}$ \\
\hline R from North Census Division & $\begin{array}{l}-0.063^{*} \\
{[0.025]}\end{array}$ & $\begin{array}{c}1.093 \\
{[0.131]}\end{array}$ & $\begin{array}{l}-0.037 \\
{[0.024]}\end{array}$ & $\begin{array}{c}1.061 \\
{[0.121]}\end{array}$ & $\begin{array}{l}-0.060^{*} \\
{[0.027]}\end{array}$ & $\begin{array}{c}1.051 \\
{[0.163]}\end{array}$ & $\begin{array}{l}-0.047 \\
{[0.024]}\end{array}$ & $\begin{array}{c}1.029 \\
{[0.143]}\end{array}$ \\
\hline R from Midwest Census Division & $\begin{array}{c}-0.007 \\
{[0.022]}\end{array}$ & $\begin{array}{l}1.298^{\star \star} \\
{[0.119]}\end{array}$ & $\begin{array}{c}0.025 \\
{[0.021]}\end{array}$ & $\begin{array}{l}1.427^{\star \star} \\
{[0.126]}\end{array}$ & $\begin{array}{c}0.019 \\
{[0.025]} \\
\end{array}$ & $\begin{array}{l}1.356^{\star \star} \\
{[0.159]}\end{array}$ & $\begin{array}{c}0.033 \\
{[0.023]} \\
\end{array}$ & $\begin{array}{l}1.410^{\star \star} \\
{[0.149]}\end{array}$ \\
\hline R from West Census Division & $\begin{array}{c}-0.026 \\
{[0.027]}\end{array}$ & $\begin{array}{c}1.207 \\
{[0.134]}\end{array}$ & $\begin{array}{c}-0.028 \\
{[0.025]}\end{array}$ & $\begin{array}{c}1.075 \\
{[0.119]}\end{array}$ & $\begin{array}{c}0.035 \\
{[0.032]}\end{array}$ & $\begin{array}{l}1.385^{\star} \\
{[0.198]}\end{array}$ & $\begin{array}{c}-0.02 \\
{[0.027]}\end{array}$ & $\begin{array}{c}1.02 \\
{[0.144]}\end{array}$ \\
\hline R has less than High School Diploma or GED & $\begin{array}{c}0.001 \\
{[0.027]} \\
\end{array}$ & $\begin{array}{c}0.973 \\
{[0.107]}\end{array}$ & $\begin{array}{l}-0.044 \\
{[0.024]}\end{array}$ & $\begin{array}{c}0.800^{\star} \\
{[0.087]}\end{array}$ & $\begin{array}{l}-0.019 \\
{[0.029]}\end{array}$ & $\begin{array}{c}0.896 \\
{[0.125]} \\
\end{array}$ & $\begin{array}{c}-0.075^{\star \star} \\
{[0.024]}\end{array}$ & $\begin{array}{l}0.662^{\star \star} \\
{[0.088]}\end{array}$ \\
\hline R has Some College but No Degree & $\begin{array}{l}-0.003 \\
{[0.024]}\end{array}$ & $\begin{array}{c}0.961 \\
{[0.097]}\end{array}$ & $\begin{array}{c}0.008 \\
{[0.023]}\end{array}$ & $\begin{array}{c}1.056 \\
{[0.100]}\end{array}$ & $\begin{array}{c}-0.011 \\
{[0.026]}\end{array}$ & $\begin{array}{c}0.972 \\
{[0.125]}\end{array}$ & $\begin{array}{c}0.005 \\
{[0.024]}\end{array}$ & $\begin{array}{c}1.067 \\
{[0.122]}\end{array}$ \\
\hline R has College Degree or More & $\begin{array}{c}0 \\
{[0.025]}\end{array}$ & $\begin{array}{c}0.981 \\
{[0.099]}\end{array}$ & $\begin{array}{c}0.017 \\
{[0.024]}\end{array}$ & $\begin{array}{c}1.034 \\
{[0.101]}\end{array}$ & $\begin{array}{c}-0.01 \\
{[0.027]}\end{array}$ & $\begin{array}{c}0.944 \\
{[0.122]}\end{array}$ & $\begin{array}{c}0.016 \\
{[0.025]}\end{array}$ & $\begin{array}{c}1.022 \\
{[0.121]}\end{array}$ \\
\hline Wave of retirement dummies & Yes & No & Yes & No & Yes & No & Yes & No \\
\hline Observations & 2697 & 6484 & 2979 & 7110 & 1958 & 4598 & 2391 & 5650 \\
\hline
\end{tabular}

Standard errors in brackets. * significant at $5 \%$; ** significant at $1 \%$

(1) In the probit analyses, "ever unretired" is the dependent variable. In the survival time analyses, "unretired in the current wave" is the dependent variable. 
Table 8: Probit and Survival Analysis of Unretirement Using Demographic and Health Controls

\begin{tabular}{|c|c|c|c|c|c|c|c|c|}
\hline \multirow{3}{*}{ Under-65 Sample } & \multicolumn{2}{|c|}{$\begin{array}{c}\text { Self-reported } \\
\text { Retirement Status } \\
\text { Directional Definition }\end{array}$} & \multicolumn{2}{|c|}{$\begin{array}{l}\text { Rand Labor Force } \\
\text { Status } \\
\text { Directional Definition }\end{array}$} & \multicolumn{2}{|c|}{$\begin{array}{c}\text { Self-reported } \\
\text { Retirement Status } \\
\text { Full-retirement Only } \\
\text { Definition }\end{array}$} & \multicolumn{2}{|c|}{$\begin{array}{c}\text { Rand Labor Force } \\
\text { Status } \\
\text { Full-retirement Only } \\
\text { Definition }\end{array}$} \\
\hline & Probit (1) & $\begin{array}{c}\text { Survival } \\
\text { Time }\end{array}$ & Probit & $\begin{array}{c}\text { Survival } \\
\text { Time }\end{array}$ & Probit & $\begin{array}{c}\text { Survival } \\
\text { Time }\end{array}$ & Probit & $\begin{array}{c}\text { Survival } \\
\text { Time }\end{array}$ \\
\hline & $\begin{array}{c}\text { Marginal } \\
\text { Impact }\end{array}$ & $\begin{array}{c}\text { Hazard } \\
\text { Ratio }\end{array}$ & $\begin{array}{l}\text { Marginal } \\
\text { Impact }\end{array}$ & $\begin{array}{l}\text { Hazard } \\
\text { Ratio }\end{array}$ & $\begin{array}{l}\text { Marginal } \\
\text { Impact }\end{array}$ & $\begin{array}{l}\text { Hazard } \\
\text { Ratio }\end{array}$ & $\begin{array}{l}\text { Marginal } \\
\text { Impact }\end{array}$ & $\begin{array}{c}\text { Hazard } \\
\text { Ratio }\end{array}$ \\
\hline Age in Years at Retirement Wave & $\begin{array}{c}-0.017^{\star \star} \\
{[0.006]}\end{array}$ & $\begin{array}{l}1.071^{\star \star} \\
{[0.024]}\end{array}$ & $\begin{array}{c}-0.039^{\star *} \\
{[0.004]}\end{array}$ & $\begin{array}{l}1.082^{\star \star} \\
{[0.024]}\end{array}$ & $\begin{array}{c}-0.033^{\star \star} \\
{[0.005]}\end{array}$ & $\begin{array}{l}1.122^{\star \star} \\
{[0.040]}\end{array}$ & $\begin{array}{l}-0.033^{\star \star} \\
{[0.004]}\end{array}$ & $\begin{array}{l}1.100^{\star \star} \\
{[0.031]}\end{array}$ \\
\hline Male & $\begin{array}{l}-0.111^{*} \\
{[0.050]}\end{array}$ & $\begin{array}{l}0.522^{\star \star} \\
{[0.129]}\end{array}$ & $\begin{array}{c}-0.075 \\
{[0.046]}\end{array}$ & $\begin{array}{c}0.761 \\
{[0.176]}\end{array}$ & $\begin{array}{l}-0.113^{*} \\
{[0.055]}\end{array}$ & $\begin{array}{c}0.464^{*} \\
{[0.152]} \\
\end{array}$ & $\begin{array}{l}-0.096^{*} \\
{[0.048]} \\
\end{array}$ & $\begin{array}{c}0.662 \\
{[0.183]} \\
\end{array}$ \\
\hline Married or "Partnered", includes Absent Spouse & $\begin{array}{c}-0.056 \\
{[0.040]} \\
\end{array}$ & $\begin{array}{c}0.986 \\
{[0.154]}\end{array}$ & $\begin{array}{c}-0.053 \\
{[0.037]}\end{array}$ & $\begin{array}{c}0.954 \\
{[0.151]} \\
\end{array}$ & $\begin{array}{l}-0.111^{*} \\
{[0.049]}\end{array}$ & $\begin{array}{c}0.726 \\
{[0.149]} \\
\end{array}$ & $\begin{array}{l}-0.091^{*} \\
{[0.043]}\end{array}$ & $\begin{array}{c}0.851 \\
{[0.162]}\end{array}$ \\
\hline Married and Male & $\begin{array}{l}0.181^{* *} \\
{[0.063]} \\
\end{array}$ & $\begin{array}{l}2.118^{\star \star} \\
{[0.578]}\end{array}$ & $\begin{array}{c}0.072 \\
{[0.055]} \\
\end{array}$ & $\begin{array}{c}1.379 \\
{[0.353]}\end{array}$ & $\begin{array}{c}0.188^{*} \\
{[0.073]} \\
\end{array}$ & $\begin{array}{l}2.838^{\star \star} \\
{[1.035]}\end{array}$ & $\begin{array}{c}0.111 \\
{[0.060]} \\
\end{array}$ & $\begin{array}{c}1.673 \\
{[0.514]}\end{array}$ \\
\hline R \& SP retired at R's Retirement Wave & $\begin{array}{c}-0.085^{\star \star} \\
{[0.024]}\end{array}$ & & $\begin{array}{l}-0.057^{*} \\
{[0.022]}\end{array}$ & & $\begin{array}{c}-0.089^{\star \star} \\
{[0.028]}\end{array}$ & & $\begin{array}{l}-0.060^{\star} \\
{[0.024]}\end{array}$ & \\
\hline R \& SP retired in Previous Wave & & $\begin{array}{l}0.487^{\star \star} \\
{[0.056]}\end{array}$ & & $\begin{array}{l}0.583^{\star \star} \\
{[0.066]}\end{array}$ & & $\begin{array}{l}0.486^{\star \star} \\
{[0.082]}\end{array}$ & & $\begin{array}{l}0.450^{\star \star} \\
{[0.070]}\end{array}$ \\
\hline $\begin{array}{l}\text { Total Wealth (in 100,000s) in } 2000 \text { \$'s at time of } \\
\text { Retirement }\end{array}$ & $\begin{array}{l}-0.001 \\
{[0.002]} \\
\end{array}$ & $\begin{array}{c}1.001 \\
{[0.009]} \\
\end{array}$ & $\begin{array}{c}0.001 \\
{[0.001]}\end{array}$ & $\begin{array}{c}1.007 \\
{[0.008]}\end{array}$ & $\begin{array}{l}-0.001 \\
{[0.002]} \\
\end{array}$ & $\begin{array}{c}1.005 \\
{[0.011]} \\
\end{array}$ & $\begin{array}{c}0 \\
{[0.002]} \\
\end{array}$ & $\begin{array}{c}1.007 \\
{[0.012]}\end{array}$ \\
\hline $\begin{array}{l}\text { Self-rated 'Poor' or 'Fair' Health at Retirement } \\
\text { Wave }\end{array}$ & $\begin{array}{c}-0.192^{\star *} \\
{[0.028]} \\
\end{array}$ & & $\begin{array}{c}-0.147^{\star \star} \\
{[0.027]}\end{array}$ & & $\begin{array}{c}-0.179^{\star \star} \\
{[0.031]} \\
\end{array}$ & & $\begin{array}{c}-0.159^{* *} \\
{[0.027]} \\
\end{array}$ & \\
\hline Self-rated 'Poor' or 'Fair' Health at Previous Wave & & $\begin{array}{l}0.429^{\star \star} \\
{[0.082]}\end{array}$ & & $\begin{array}{l}0.381^{\star \star} \\
{[0.077]}\end{array}$ & & $\begin{array}{l}0.383^{\star \star} \\
{[0.099]}\end{array}$ & & $\begin{array}{l}0.308^{\star \star} \\
{[0.080]}\end{array}$ \\
\hline $\begin{array}{l}\text { Male \& Self-rated 'Poor' or 'Fair' Health at } \\
\text { Retirement Wave }\end{array}$ & $\begin{array}{c}0.111 \\
{[0.067]}\end{array}$ & & $\begin{array}{c}0.09 \\
{[0.059]}\end{array}$ & & $\begin{array}{c}0.148 \\
{[0.079]}\end{array}$ & & $\begin{array}{l}0.164^{*} \\
{[0.069]}\end{array}$ & \\
\hline $\begin{array}{l}\text { Male \& Self-rated 'Poor' or 'Fair' Health at } \\
\text { Previous Wave }\end{array}$ & & $\begin{array}{c}1.434 \\
{[0.389]}\end{array}$ & & $\begin{array}{l}1.846^{*} \\
{[0.506]}\end{array}$ & & $\begin{array}{c}1.397 \\
{[0.508]}\end{array}$ & & $\begin{array}{l}2.413^{* *} \\
{[0.811]}\end{array}$ \\
\hline $\begin{array}{l}\text { Spouse Self-rated 'Poor' or 'Fair' Health at } \\
\text { Retirement Wave }\end{array}$ & $\begin{array}{c}0.075 \\
{[0.050]}\end{array}$ & & $\begin{array}{c}0.049 \\
{[0.043]}\end{array}$ & & $\begin{array}{l}0.150^{*} \\
{[0.063]}\end{array}$ & & $\begin{array}{c}0.077 \\
{[0.047]}\end{array}$ & \\
\hline $\begin{array}{l}\text { Spouse Self-rated 'Poor' or 'Fair' Health at } \\
\text { Previous Wave }\end{array}$ & & $\begin{array}{c}1.195 \\
{[0.236]}\end{array}$ & & $\begin{array}{c}1.081 \\
{[0.213]}\end{array}$ & & $\begin{array}{c}1.619 \\
{[0.411]}\end{array}$ & & $\begin{array}{c}1.406 \\
{[0.322]}\end{array}$ \\
\hline $\begin{array}{l}\text { Male \& Spouse Self-rated 'Poor' or 'Fair' Health at } \\
\text { Retirement Wave }\end{array}$ & $\begin{array}{c}-0.011 \\
{[0.066]}\end{array}$ & & $\begin{array}{l}-0.016 \\
{[0.057]}\end{array}$ & & $\begin{array}{l}-0.105^{*} \\
{[0.052]}\end{array}$ & & $\begin{array}{l}-0.054 \\
{[0.050]}\end{array}$ & \\
\hline $\begin{array}{l}\text { Male \& Spouse Self-rated 'Poor' or 'Fair' Health at } \\
\text { Previous Wave }\end{array}$ & & $\begin{array}{c}1.016 \\
{[0.282]}\end{array}$ & & $\begin{array}{c}0.886 \\
{[0.265]}\end{array}$ & & $\begin{array}{c}0.837 \\
{[0.304]} \\
\end{array}$ & & $\begin{array}{c}0.754 \\
{[0.262]}\end{array}$ \\
\hline R Reports Being "Other Race" & $\begin{array}{c}0.137 \\
{[0.083]}\end{array}$ & $\begin{array}{l}1.847^{\star} \\
{[0.522]} \\
\end{array}$ & $\begin{array}{c}0.095 \\
{[0.075]} \\
\end{array}$ & $\begin{array}{c}1.714 \\
{[0.549]} \\
\end{array}$ & $\begin{array}{c}0.09 \\
{[0.103]}\end{array}$ & $\begin{array}{c}1.741 \\
{[0.731]} \\
\end{array}$ & $\begin{array}{c}0.102 \\
{[0.088]}\end{array}$ & $\begin{array}{c}1.815 \\
{[0.725]}\end{array}$ \\
\hline R Reports Being Black & $\begin{array}{c}0.036 \\
{[0.035]}\end{array}$ & $\begin{array}{c}1.224 \\
{[0.178]} \\
\end{array}$ & $\begin{array}{c}0.034 \\
{[0.031]}\end{array}$ & $\begin{array}{c}1.256 \\
{[0.188]} \\
\end{array}$ & $\begin{array}{c}0.037 \\
{[0.042]} \\
\end{array}$ & $\begin{array}{l}1.474^{\star} \\
{[0.269]} \\
\end{array}$ & $\begin{array}{c}0.057 \\
{[0.034]}\end{array}$ & $\begin{array}{c}1.259 \\
{[0.228]} \\
\end{array}$ \\
\hline R Reports Being Hispanic & $\begin{array}{c}0.021 \\
{[0.056]}\end{array}$ & $\begin{array}{c}1.098 \\
{[0.250]}\end{array}$ & $\begin{array}{c}0.018 \\
{[0.050]}\end{array}$ & $\begin{array}{c}1.044 \\
{[0.251]}\end{array}$ & $\begin{array}{c}0.012 \\
{[0.062]}\end{array}$ & $\begin{array}{c}0.984 \\
{[0.306]}\end{array}$ & $\begin{array}{c}0.02 \\
{[0.053]}\end{array}$ & $\begin{array}{c}0.874 \\
{[0.276]} \\
\end{array}$ \\
\hline R from North Census Division & $\begin{array}{l}-0.049 \\
{[0.030]}\end{array}$ & $\begin{array}{c}1.015 \\
{[0.159]}\end{array}$ & $\begin{array}{c}-0.02 \\
{[0.028]}\end{array}$ & $\begin{array}{c}0.991 \\
{[0.153]}\end{array}$ & $\begin{array}{l}-0.047 \\
{[0.035]}\end{array}$ & $\begin{array}{c}0.968 \\
{[0.214]}\end{array}$ & $\begin{array}{c}-0.027 \\
{[0.030]}\end{array}$ & $\begin{array}{c}1.063 \\
{[0.201]}\end{array}$ \\
\hline R from Midwest Census Division & $\begin{array}{c}-0.012 \\
{[0.027]}\end{array}$ & $\begin{array}{l}1.310^{\star} \\
{[0.159]}\end{array}$ & $\begin{array}{c}0.012 \\
{[0.025]}\end{array}$ & $\begin{array}{l}1.452^{\star \star} \\
{[0.178]}\end{array}$ & $\begin{array}{c}0.027 \\
{[0.032]}\end{array}$ & $\begin{array}{c}1.443^{\star} \\
{[0.239]}\end{array}$ & $\begin{array}{c}0.026 \\
{[0.027]}\end{array}$ & $\begin{array}{l}1.524^{\star \star} \\
{[0.229]}\end{array}$ \\
\hline R from West Census Division & $\begin{array}{l}-0.025 \\
{[0.032]} \\
\end{array}$ & $\begin{array}{c}1.163 \\
{[0.168]} \\
\end{array}$ & $\begin{array}{c}0.018 \\
{[0.031]}\end{array}$ & $\begin{array}{c}1.055 \\
{[0.155]} \\
\end{array}$ & $\begin{array}{c}0.055 \\
{[0.042]}\end{array}$ & $\begin{array}{c}1.342 \\
{[0.287]} \\
\end{array}$ & $\begin{array}{c}0.03 \\
{[0.036]}\end{array}$ & $\begin{array}{c}1.045 \\
{[0.205]}\end{array}$ \\
\hline R has less than High School Diploma or GED & $\begin{array}{c}-0.01 \\
{[0.034]}\end{array}$ & $\begin{array}{c}0.896 \\
{[0.144]}\end{array}$ & $\begin{array}{c}0.007 \\
{[0.031]}\end{array}$ & $\begin{array}{c}0.739 \\
{[0.126]}\end{array}$ & $\begin{array}{l}-0.001 \\
{[0.040]}\end{array}$ & $\begin{array}{c}0.844 \\
{[0.175]}\end{array}$ & $\begin{array}{c}0.002 \\
{[0.032]}\end{array}$ & $\begin{array}{l}0.583^{\star \star} \\
{[0.122]}\end{array}$ \\
\hline R has Some College but No Degree & $\begin{array}{l}-0.022 \\
{[0.029]}\end{array}$ & $\begin{array}{c}0.928 \\
{[0.125]}\end{array}$ & $\begin{array}{l}-0.001 \\
{[0.026]}\end{array}$ & $\begin{array}{c}1.241 \\
{[0.158]}\end{array}$ & $\begin{array}{l}-0.023 \\
{[0.033]}\end{array}$ & $\begin{array}{c}1.015 \\
{[0.190]}\end{array}$ & $\begin{array}{c}-0.011 \\
{[0.028]}\end{array}$ & $\begin{array}{c}1.35 \\
{[0.212]}\end{array}$ \\
\hline R has College Degree or More & $\begin{array}{c}-0.015 \\
{[0.028]}\end{array}$ & $\begin{array}{c}0.918 \\
{[0.120]}\end{array}$ & $\begin{array}{l}-0.012 \\
{[0.026]}\end{array}$ & $\begin{array}{c}1.07 \\
{[0.141]}\end{array}$ & $\begin{array}{c}0 \\
{[0.034]}\end{array}$ & $\begin{array}{c}0.949 \\
{[0.171]}\end{array}$ & $\begin{array}{c}-0.002 \\
{[0.029]}\end{array}$ & $\begin{array}{c}1.138 \\
{[0.187]}\end{array}$ \\
\hline Wave of retirement dummies & Yes & No & Yes & No & Yes & No & Yes & No \\
\hline Observations & 1722 & 2929 & 1850 & 3162 & 1100 & 1864 & 1388 & 2424 \\
\hline
\end{tabular}

Standard errors in brackets. * significant at $5 \%$; ${ }^{*}$ significant at $1 \%$

(1) In the probit analyses, "ever unretired" is the dependent variable. In the survival time analyses, "unretired in the current wave" is the dependent variable. 
Table 9: Probit and Survival Analysis of Unretirement using Health Insurance and Pensions Controls

\begin{tabular}{|c|c|c|c|c|c|c|c|c|}
\hline \multirow{3}{*}{ Full-Sample } & \multicolumn{2}{|c|}{$\begin{array}{c}\text { Self-reported Retirement Status } \\
\text { Directional Definition }\end{array}$} & \multicolumn{2}{|c|}{$\begin{array}{c}\text { Rand Labor Force Status } \\
\text { Directional Definition }\end{array}$} & \multicolumn{2}{|c|}{$\begin{array}{l}\text { Self-reported Retirement Status } \\
\text { Full-retirement Only Definition }\end{array}$} & \multicolumn{2}{|c|}{$\begin{array}{c}\text { Rand Labor Force Status } \\
\text { Full-retirement Only Definition }\end{array}$} \\
\hline & Probit (1) & Survival Time & \begin{tabular}{|l|} 
Probit \\
\end{tabular} & Survival Time & \begin{tabular}{|l|} 
Probit \\
\end{tabular} & Survival Time & Probit & Survival Time \\
\hline & Marginal Impact & Hazard Ratio & Marginal Impact & Hazard Ratio & Marginal Impact & Hazard Ratio & Marginal Impact & Hazard Ratio \\
\hline $\begin{array}{l}\text { Respondent }(\mathrm{R}) \text { Has No Health } \\
\text { Insurance at Retirement Wave }\end{array}$ & $\begin{array}{|ll|}0.096^{\star *} & 0.100^{\star *} \\
{[0.033]} & {[0.035]} \\
\end{array}$ & & $\begin{array}{ll}0.084^{\star *} & 0.131^{\star \star} \\
{[0.030]} & {[0.033]} \\
\end{array}$ & & \begin{tabular}{cc|}
$0.088^{*}$ & $0.093^{*}$ \\
{$[0.040]$} & {$[0.043]$} \\
\end{tabular} & & \begin{tabular}{cc|}
0.049 & $0.104^{\star \star}$ \\
{$[0.034]$} & {$[0.038]$} \\
\end{tabular} & \\
\hline $\begin{array}{l}\text { Respondent (R) Has No Health } \\
\text { Insurance in Previous Wave }\end{array}$ & & $\begin{array}{ll}2.329^{* *} & 2.341^{* *} \\
{[0.277]} & {[0.296]}\end{array}$ & & $\begin{array}{ll}1.998^{\star *} & 2.242^{\star \star} \\
{[0.235]} & {[0.283]}\end{array}$ & & \begin{tabular}{|ll}
$2.344^{\star *}$ & $2.531^{\star *}$ \\
{$[0.399]$} & {$[0.462]$}
\end{tabular} & & $\begin{array}{ll}1.572^{\star *} & 1.878^{\star \star} \\
{[0.257]} & {[0.328]}\end{array}$ \\
\hline $\begin{array}{l}\text { R Buys Private Health Insurance at } \\
\text { Retirement Wave }\end{array}$ & \begin{tabular}{cc|}
0.033 & 0.038 \\
{$[0.039]$} & {$[0.040]$} \\
\end{tabular} & & \begin{tabular}{cc|}
0.055 & 0.056 \\
{$[0.038]$} & {$[0.039]$} \\
\end{tabular} & & $\begin{array}{cc}0.112^{*} & 0.097 \\
{[0.051]} & {[0.052]} \\
\end{array}$ & & \begin{tabular}{cc|}
0.073 & 0.062 \\
{$[0.043]$} & {$[0.043]$} \\
\end{tabular} & \\
\hline $\begin{array}{l}\text { R Buys Private Health Insurance in } \\
\text { Previous Wave }\end{array}$ & & $\begin{array}{cc}1.053 & 1.091 \\
{[0.151]} & {[0.162]} \\
\end{array}$ & & $\begin{array}{cc}1.044 & 1.014 \\
{[0.147]} & {[0.148]} \\
\end{array}$ & & $\begin{array}{cc}1.377 & 1.306 \\
{[0.271]} & {[0.266]} \\
\end{array}$ & & $\begin{array}{cc}1.205 & 1.12 \\
{[0.209]} & {[0.200]}\end{array}$ \\
\hline $\begin{array}{l}\text { Unsubsidized Employer Provide Health } \\
\text { Insurance at Retirement Wave }\end{array}$ & $\begin{array}{|cc|}0.058^{\star} & 0.048 \\
{[0.027]} & {[0.028]} \\
\end{array}$ & & \begin{tabular}{cc|}
0.035 & 0.033 \\
{$[0.026]$} & {$[0.027]$} \\
\end{tabular} & & $\begin{array}{cc}0.031 & 0.023 \\
{[0.030]} & {[0.031]} \\
\end{array}$ & & \begin{tabular}{cc|}
0.033 & 0.029 \\
{$[0.027]$} & {$[0.028]$} \\
\end{tabular} & \\
\hline $\begin{array}{l}\text { Unsubsidized Employer Provide Health } \\
\text { Insurance in Previous Wave }\end{array}$ & & $\begin{array}{|ll|}1.855^{* *} & 1.800^{* *} \\
{[0.204]} & {[0.209]} \\
\end{array}$ & & $\begin{array}{|ll|}1.767^{\star *} & 1.791^{\star \star} \\
{[0.187]} & {[0.197]} \\
\end{array}$ & & $\begin{array}{|ll|}1.720^{\star *} & 1.796^{\star *} \\
{[0.244]} & {[0.273]} \\
\end{array}$ & & $\begin{array}{ll}1.741^{\star *} & 1.764^{\star *} \\
{[0.222]} & {[0.235]} \\
\end{array}$ \\
\hline $\begin{array}{l}\text { R Receives Pension at Retirement } \\
\text { Wave }\end{array}$ & \begin{tabular}{cc|}
$-0.038^{*}$ & $-0.060 * \star$ \\
{$[0.019]$} & {$[0.019]$} \\
\end{tabular} & & $\begin{array}{|cc|}-0.026 & -0.046^{*} \\
{[0.017]} & {[0.018]} \\
\end{array}$ & & \begin{tabular}{cc|}
0.018 & -0.008 \\
{$[0.020]$} & {$[0.021]$} \\
\end{tabular} & & \begin{tabular}{cc|}
-0.015 & -0.037 \\
{$[0.018]$} & {$[0.019]$} \\
\end{tabular} & \\
\hline R Receives Pension in Previous Wave & & \begin{tabular}{cc|}
$0.857^{\star}$ & $0.780^{\star \star}$ \\
{$[0.065]$} & {$[0.061]$} \\
\end{tabular} & & $\begin{array}{ll}0.808^{* \star} & 0.722^{\star \star} \\
{[0.059]} & {[0.055]}\end{array}$ & & \begin{tabular}{cc|}
1.021 & 0.889 \\
{$[0.097]$} & {$[0.087]$} \\
\end{tabular} & & $\begin{array}{cc}0.824^{\star} & 0.709^{\star \star} \\
{[0.072]} & {[0.064]} \\
\end{array}$ \\
\hline $\begin{array}{l}\text { Demographic, Health, and Wealth } \\
\text { Controls }\end{array}$ & Yes & Yes & Yes & Yes & Yes & Yes & Yes & Yes \\
\hline Wave of retirement dummies & Yes & No & Yes & No & Yes & No & Yes & No \\
\hline Observations & 2697 & 6363 & 3030 & 7054 & 1993 & 4586 & 2436 & 5558 \\
\hline
\end{tabular}

Standard errors in brackets. * significant at $5 \%$; ** significant at $1 \%$

(1) In the probit analyses, "ever unretired" is the dependent variable. In the survival time analyses, "unretired in the current wave" is the dependent variable. 


\begin{tabular}{|c|c|c|c|c|c|c|c|c|}
\hline \multirow{3}{*}{ Under-65 Sample } & \multicolumn{2}{|c|}{$\begin{array}{c}\text { Self-reported Retirement Status } \\
\text { Directional Definition }\end{array}$} & \multicolumn{2}{|c|}{$\begin{array}{c}\text { Rand Labor Force Status } \\
\text { Directional Definition }\end{array}$} & \multicolumn{2}{|c|}{$\begin{array}{l}\text { Self-reported Retirement Status } \\
\text { Full-retirement Only Definition }\end{array}$} & \multicolumn{2}{|c|}{$\begin{array}{l}\text { Rand Labor Force Status } \\
\text { Full-retirement Only Definition }\end{array}$} \\
\hline & Probit (1) & Survival Time & \begin{tabular}{l|l} 
Probit & \\
\end{tabular} & Survival Time & \begin{tabular}{c|} 
Probit \\
\end{tabular} & Survival Time & \begin{tabular}{l|l} 
Probit \\
\end{tabular} & Survival Time \\
\hline & Marginal Impact & Hazard Ratio & Marginal Impact & Hazard Ratio & Marginal Impact & Hazard Ratio & Marginal Impact & Hazard Ratio \\
\hline $\begin{array}{l}\text { Respondent (R) Has No Health } \\
\text { Insurance at Retirement Wave }\end{array}$ & \begin{tabular}{ll|}
$0.133^{\star \star}$ & $0.172^{\star \star}$ \\
{$[0.042]$} & {$[0.047]$} \\
\end{tabular} & & \begin{tabular}{cc|}
$0.091^{*}$ & $0.116^{\star *}$ \\
{$[0.037]$} & {$[0.041]$} \\
\end{tabular} & & \begin{tabular}{cc|}
$0.132^{\star}$ & $0.166^{\star \star}$ \\
{$[0.054]$} & {$[0.060]$} \\
\end{tabular} & & $\begin{array}{cc}0.085^{\star} & 0.109^{\star} \\
{[0.042]} & {[0.047]} \\
\end{array}$ & \\
\hline $\begin{array}{l}\text { Respondent (R) Has No Health } \\
\text { Insurance in Previous Wave }\end{array}$ & & $\begin{array}{ll}1.974^{\star \star} & 2.135^{\star \star} \\
{[0.295]} & {[0.347]} \\
\end{array}$ & & $\begin{array}{ll}1.967^{\star \star} & 2.252^{\star \star} \\
{[0.291]} & {[0.363]} \\
\end{array}$ & & \begin{tabular}{ll|}
$2.445^{\star \star}$ & $2.367^{\star \star}$ \\
{$[0.521]$} & {$[0.616]$} \\
\end{tabular} & & $\begin{array}{ll}1.993^{\star *} & 2.267^{* *} \\
{[0.380]} & {[0.476]} \\
\end{array}$ \\
\hline $\begin{array}{l}\text { R Buys Private Health Insurance at } \\
\text { Retirement Wave }\end{array}$ & $\begin{array}{cc}0.025 & 0.016 \\
{[0.046]} & {[0.047]}\end{array}$ & & $\begin{array}{cc}0.051 & 0.036 \\
{[0.044]} & {[0.044]}\end{array}$ & & $\begin{array}{cc}0.119 & 0.087 \\
{[0.064]} & {[0.065]}\end{array}$ & & $\begin{array}{cc}0.105 & 0.071 \\
{[0.054]} & {[0.053]}\end{array}$ & \\
\hline $\begin{array}{l}\text { R Buys Private Health Insurance in } \\
\text { Previous Wave }\end{array}$ & & $\begin{array}{cc}0.94 & 0.935 \\
{[0.173]} & {[0.177]}\end{array}$ & & $\begin{array}{cc}1.066 & 0.986 \\
{[0.190]} & {[0.182]}\end{array}$ & & $\begin{array}{cc}1.435 & 1.266 \\
{[0.382]} & {[0.344]}\end{array}$ & & $\begin{array}{cc}1.326 & 1.206 \\
{[0.295]} & {[0.274]}\end{array}$ \\
\hline $\begin{array}{l}\text { Unsubsidized Employer Provide Health } \\
\text { Insurance at Retirement Wave }\end{array}$ & \begin{tabular}{cc|}
0.035 & 0.031 \\
{$[0.032]$} & {$[0.033]$} \\
\end{tabular} & & \begin{tabular}{cc|}
0.015 & 0.009 \\
{$[0.029]$} & {$[0.030]$} \\
\end{tabular} & & $\begin{array}{cc}0 & -0.006 \\
{[0.036]} & {[0.037]} \\
\end{array}$ & & \begin{tabular}{cc|}
0.001 & -0.006 \\
{$[0.032]$} & {$[0.032]$} \\
\end{tabular} & \\
\hline $\begin{array}{l}\text { Unsubsidized Employer Provide Health } \\
\text { Insurance in Previous Wave }\end{array}$ & & $\begin{array}{cc}1.406^{*} & 1.377^{\star} \\
{[0.189]} & {[0.192]} \\
\end{array}$ & & \begin{tabular}{ll|}
$1.431^{\star *}$ & $1.412^{*}$ \\
{$[0.191]$} & {$[0.193]$} \\
\end{tabular} & & \begin{tabular}{cc|}
1.304 & 1.266 \\
{$[0.244]$} & {$[0.242]$} \\
\end{tabular} & & $\begin{array}{ll}1.463^{\star} & 1.411^{\star} \\
{[0.242]} & {[0.241]} \\
\end{array}$ \\
\hline $\begin{array}{l}\text { R Receives Pension at Retirement } \\
\text { Wave }\end{array}$ & $\begin{array}{cc}-0.009 & -0.047^{*} \\
{[0.023]} & {[0.024]}\end{array}$ & & $\begin{array}{cc}-0.01 & -0.038 \\
{[0.021]} & {[0.022]}\end{array}$ & & $\begin{array}{cc}0.056^{*} & 0.021 \\
{[0.027]} & {[0.028]}\end{array}$ & & $\begin{array}{cc}0.023 & -0.007 \\
{[0.023]} & {[0.024]}\end{array}$ & \\
\hline R Receives Pension in Previous Wave & & $\begin{array}{cc}0.88 & 0.758^{*} \\
{[0.091]} & {[0.082]} \\
\end{array}$ & & \begin{tabular}{cc|}
0.918 & $0.778^{*}$ \\
{$[0.095]$} & {$[0.084]$} \\
\end{tabular} & & \begin{tabular}{cc|}
1.251 & 1.021 \\
{$[0.172]$} & {$[0.150]$} \\
\end{tabular} & & $\begin{array}{cc}1.039 & 0.86 \\
{[0.130]} & {[0.112]} \\
\end{array}$ \\
\hline $\begin{array}{l}\text { Demographic, Health, and Wealth } \\
\text { Controls }\end{array}$ & Yes & Yes & Yes & Yes & Yes & Yes & Yes & Yes \\
\hline Wave of retirement dummies & Yes & No & Yes & No & Yes & No & Yes & No \\
\hline Observations & 1722 & 2890 & 1850 & 3121 & 1100 & 1849 & 1417 & 2405 \\
\hline
\end{tabular}

Standard errors in brackets. * significant at 5\%; ** significant at $1 \%$

(1) In the probit analyses, "ever unretired" is the dependent variable. In the survival time analyses, "unretired in the current wave" is the dependent variable. 
Table 11: Probit and Survival Analysis of Unretirement using Shocks, Health Insurance and Pensions Controls

\begin{tabular}{|c|c|c|c|c|c|c|c|c|}
\hline \multirow[t]{3}{*}{ Full Sample } & \multicolumn{2}{|c|}{$\begin{array}{c}\text { Self-reported Retirement Status } \\
\text { Directional Definition }\end{array}$} & \multicolumn{2}{|c|}{$\begin{array}{l}\text { Rand Labor Force Status } \\
\text { Directional Definition }\end{array}$} & \multicolumn{2}{|c|}{$\begin{array}{l}\text { Self-reported Retirement Status } \\
\text { Full-retirement Only Definition }\end{array}$} & \multicolumn{2}{|c|}{$\begin{array}{l}\text { Rand Labor Force Status } \\
\text { Full-retirement Only Definition }\end{array}$} \\
\hline & Probit (2) & Survival Time & Probit & Survival Time & Probit & Survival Time & Probit & Survival Time \\
\hline & Marginal Impact & Hazard Ratio & Marginal Impact & Hazard Ratio & Marginal Impact & Hazard Ratio & Marginal Impact & Hazard Ratio \\
\hline $\begin{array}{l}\text { Respondent (R) Has No Health } \\
\text { Insurance at Retirement Wave (RW) }\end{array}$ & \begin{tabular}{ll|}
$0.089^{* *}$ & $0.097^{\star *}$ \\
{$[0.033]$} & {$[0.035]$} \\
\end{tabular} & & \begin{tabular}{ll|}
$0.084^{\star \star}$ & $0.134^{\star *}$ \\
{$[0.030]$} & {$[0.034]$} \\
\end{tabular} & & $\begin{array}{|cc|}0.082^{\star} & 0.090^{\star} \\
{[0.040]} & {[0.043]} \\
\end{array}$ & & $\begin{array}{cc}0.049 & 0.106^{\star \star} \\
{[0.034]} & {[0.038]} \\
\end{array}$ & \\
\hline $\begin{array}{l}\text { Respondent (R) Has No Health } \\
\text { Insurance in Previous Wave (PW) }\end{array}$ & & $\begin{array}{|ll|}2.305^{\star \star} & 2.331^{\star \star} \\
{[0.274]} & {[0.294]}\end{array}$ & & $\begin{array}{|ll|}1.981^{\star *} & 2.225^{\star *} \\
{[0.233]} & {[0.281]}\end{array}$ & & \begin{tabular}{ll|}
$2.316^{\star \star}$ & $2.540^{\star \star}$ \\
{$[0.390]$} & {$[0.457]$}
\end{tabular} & & $\begin{array}{ll}1.556^{\star \star} & 1.873^{\star \star} \\
{[0.253]} & {[0.325]}\end{array}$ \\
\hline $\begin{array}{l}\text { R Buys Private Health Insurance at } \\
\text { RW }\end{array}$ & \begin{tabular}{cc|}
0.032 & 0.039 \\
{$[0.039]$} & {$[0.040]$}
\end{tabular} & & $\begin{array}{cc}0.057 & 0.06 \\
{[0.038]} & {[0.039]}\end{array}$ & & $\begin{array}{|cc|}0.113^{*} & 0.099 \\
{[0.051]} & {[0.052]}\end{array}$ & & $\begin{array}{cc}0.073 & 0.064 \\
{[0.043]} & {[0.043]}\end{array}$ & \\
\hline R Buys Private Health Insurance in PW & & $\begin{array}{cc}1.056 & 1.092 \\
{[0.152]} & {[0.163]}\end{array}$ & & \begin{tabular}{cc|}
1.038 & 1.003 \\
{$[0.146]$} & {$[0.146]$}
\end{tabular} & & $\begin{array}{cc}1.384 & 1.302 \\
{[0.274]} & {[0.267]}\end{array}$ & & $\begin{array}{cc}1.199 & 1.104 \\
{[0.208]} & {[0.197]}\end{array}$ \\
\hline $\begin{array}{l}\text { Unsubsidized Employer Provide Health } \\
\text { Insurance at RW }\end{array}$ & $\begin{array}{|cc|}0.060^{*} & 0.049 \\
{[0.028]} & {[0.028]} \\
\end{array}$ & & $\begin{array}{cc}0.035 & 0.032 \\
{[0.026]} & {[0.027]}\end{array}$ & & $\begin{array}{cc}0.034 & 0.026 \\
{[0.030]} & {[0.031]}\end{array}$ & & $\begin{array}{cc}0.035 & 0.031 \\
{[0.028]} & {[0.028]}\end{array}$ & \\
\hline $\begin{array}{l}\text { Unsubsidized Employer Provide Health } \\
\text { Insurance in PW }\end{array}$ & & \begin{tabular}{ll|}
$1.861^{\star *}$ & $1.796^{\star \star}$ \\
{$[0.205]$} & {$[0.209]$}
\end{tabular} & & $\begin{array}{ll}1.760^{\star \star} & 1.781^{\star \star} \\
{[0.187]} & {[0.197]}\end{array}$ & & \begin{tabular}{ll|}
$1.735^{\star \star}$ & $1.809^{\star \star}$ \\
{$[0.247]$} & {$[0.276]$}
\end{tabular} & & $\begin{array}{ll}1.734^{\star \star} & 1.763^{\star \star} \\
{[0.221]} & {[0.236]}\end{array}$ \\
\hline R Receives Pension at RW & $\begin{array}{|cc|}-0.037^{\star} & -0.059^{\star \star} \\
{[0.019]} & {[0.019]} \\
\end{array}$ & & $\begin{array}{|cc|}-0.022 & -0.042^{*} \\
{[0.018]} & {[0.018]} \\
\end{array}$ & & \begin{tabular}{cc|}
0.022 & -0.005 \\
{$[0.020]$} & {$[0.021]$} \\
\end{tabular} & & $\begin{array}{cc}-0.011 & -0.034 \\
{[0.018]} & {[0.019]} \\
\end{array}$ & \\
\hline R Receives Pension in PW & & $\begin{array}{|ll|}0.858^{*} & 0.780^{\star \star} \\
{[0.065]} & {[0.061]}\end{array}$ & & $\begin{array}{ll}0.808^{\star *} & 0.723^{\star *} \\
{[0.059]} & {[0.055]}\end{array}$ & & $\begin{array}{cc}1.023 & 0.892 \\
{[0.097]} & {[0.087]}\end{array}$ & & $\begin{array}{ll}0.825^{\star} & 0.709^{\star \star} \\
{[0.072]} & {[0.064]}\end{array}$ \\
\hline $\begin{array}{l}\text { Wealth Drops over } 50 \% \text { \& more than } \\
\$ 10000 \text { between RW and the Next }\end{array}$ & \begin{tabular}{cc|}
0.041 & 0.036 \\
{$[0.029]$} & {$[0.030]$} \\
\end{tabular} & & $\begin{array}{|cc|}0.069^{*} & 0.066^{*} \\
{[0.027]} & {[0.028]} \\
\end{array}$ & & $\begin{array}{cc}0.063 & 0.054 \\
{[0.033]} & {[0.033]} \\
\end{array}$ & & $\begin{array}{cc}0.059^{\star} & 0.058^{\star} \\
{[0.028]} & {[0.029]}\end{array}$ & \\
\hline $\begin{array}{l}\text { Wealth Dropped over } 50 \% \& \text { more } \\
\text { than } \$ 10000 \text { before the PW }\end{array}$ & & $\begin{array}{|ll|}1.276^{*} & 1.257^{*} \\
{[0.124]} & {[0.123]}\end{array}$ & & $\begin{array}{|cc|}1.209^{*} & 1.234^{*} \\
{[0.116]} & {[0.120]} \\
\end{array}$ & & \begin{tabular}{ll|}
$1.312^{\star}$ & $1.305^{\star}$ \\
{$[0.166]$} & {$[0.169]$}
\end{tabular} & & $\begin{array}{ll}1.299^{\star} & 1.337^{\star} \\
{[0.146]} & {[0.154]}\end{array}$ \\
\hline $\begin{array}{l}\text { R's Health Declines by } 2 \text { Levels or } \\
\text { more between RW and the Next }\end{array}$ & \begin{tabular}{cc|}
0.03 & 0.009 \\
{$[0.050]$} & {$[0.050]$} \\
\end{tabular} & & $\begin{array}{|cc|}-0.117^{\star \star} & -0.139^{\star \star} \\
{[0.037]} & {[0.035]} \\
\end{array}$ & & $\begin{array}{cc}0.016 & -0.02 \\
{[0.053]} & {[0.050]} \\
\end{array}$ & & $\begin{array}{cc}-0.098^{\star} & -0.112^{\star \star} \\
{[0.039]} & {[0.036]}\end{array}$ & \\
\hline $\begin{array}{l}\text { R's Health Declines by } 2 \text { Levels or } \\
\text { more before the PW }\end{array}$ & & $\begin{array}{cc}0.921 & 1.071 \\
{[0.156]} & {[0.182]}\end{array}$ & & $\begin{array}{cc}0.754 & 0.921 \\
{[0.127]} & {[0.157]}\end{array}$ & & $\begin{array}{cc}0.98 & 1.143 \\
{[0.207]} & {[0.242]} \\
\end{array}$ & & $\begin{array}{cc}0.722 & 0.896 \\
{[0.146]} & {[0.184]}\end{array}$ \\
\hline $\begin{array}{l}\text { R's Household Size increases between } \\
\text { RW and the Next }\end{array}$ & $\begin{array}{|cc|}0.078^{*} & 0.087^{*} \\
{[0.033]} & {[0.034]} \\
\end{array}$ & & \begin{tabular}{cc|}
$0.063^{*}$ & $0.083^{*}$ \\
{$[0.031]$} & {$[0.032]$}
\end{tabular} & & \begin{tabular}{cc|}
0.071 & $0.076^{*}$ \\
{$[0.037]$} & {$[0.038]$} \\
\end{tabular} & & $\begin{array}{cc}0.013 & 0.028 \\
{[0.032]} & {[0.033]}\end{array}$ & \\
\hline $\begin{array}{l}\text { R's Household Size increases before } \\
\text { the PW }\end{array}$ & & $\begin{array}{cc}1.01 & 0.954 \\
{[0.121]} & {[0.118]}\end{array}$ & & \begin{tabular}{cc|}
1.068 & 1.054 \\
{$[0.122]$} & {$[0.126]$} \\
\end{tabular} & & \begin{tabular}{cc|}
1.216 & 1.166 \\
{$[0.178]$} & {$[0.175]$}
\end{tabular} & & $\begin{array}{cc}1.112 & 1.147 \\
{[0.149]} & {[0.159]}\end{array}$ \\
\hline $\begin{array}{l}\text { OOPM Expenses rise } 50 \% \text { \& over } \\
\$ 2,000 \text { between RW and Next (1) }\end{array}$ & \begin{tabular}{cc|}
-0.035 & -0.027 \\
{$[0.024]$} & {$[0.025]$} \\
\end{tabular} & & $\begin{array}{cc}-0.028 & -0.014 \\
{[0.023]} & {[0.024]}\end{array}$ & & \begin{tabular}{cc|}
-0.017 & -0.024 \\
{$[0.026]$} & {$[0.026]$} \\
\end{tabular} & & $\begin{array}{cc}-0.006 & -0.001 \\
{[0.024]} & {[0.024]}\end{array}$ & \\
\hline $\begin{array}{l}\text { OOPM Expenses rise } 50 \% \text { \& over } \\
\$ 2,000 \text { before } \mathrm{PW}\end{array}$ & & $\begin{array}{cc}0.889 & 0.969 \\
{[0.084]} & {[0.093]}\end{array}$ & & \begin{tabular}{cc|}
1.048 & 1.133 \\
{$[0.091]$} & {$[0.099]$} \\
\end{tabular} & & $\begin{array}{cc}0.818 & 0.908 \\
{[0.103]} & {[0.115]} \\
\end{array}$ & & $\begin{array}{cc}1.038 & 1.108 \\
{[0.107]} & 0.116]\end{array}$ \\
\hline $\begin{array}{l}\text { Demographic, Health, and Wealth } \\
\text { Controls }\end{array}$ & Yes & Yes & Yes & Yes & Yes & Yes & Yes & No Yes \\
\hline Wave of retirement dummies & Yes & No & Yes & No & Yes & No & Yes & No \\
\hline Observations & 2696 & 6361 & 2978 & 6972 & 1990 & 4581 & 2434 & 5615 \\
\hline
\end{tabular}

Standard errors in brackets. * significant at 5\%; ${ }^{* \star}$ significant at $1 \%$

(1) OOPM is Out-of-Pocket Medical Expenses

(2) In the probit analyses, "ever unretired" is the dependent variable. In the survival time analyses, "unretired in the current wave" is the dependent variable. 
Table 12: Probit and Survival Analysis of Unretirement using Shocks, Health Insurance and Pensions Controls

\begin{tabular}{|c|c|c|c|c|c|c|c|c|}
\hline \multirow[t]{3}{*}{ Under-65 Sample } & \multicolumn{2}{|c|}{$\begin{array}{c}\text { Self-reported Retirement Status } \\
\text { Directional Definition }\end{array}$} & \multicolumn{2}{|c|}{$\begin{array}{c}\text { Rand Labor Force Status } \\
\text { Directional Definition }\end{array}$} & \multicolumn{2}{|c|}{$\begin{array}{l}\text { Self-reported Retirement Status } \\
\text { Full-retirement Only Definition }\end{array}$} & \multicolumn{2}{|c|}{$\begin{array}{l}\text { Rand Labor Force Status } \\
\text { Full-retirement Only Definition }\end{array}$} \\
\hline & Probit (2) & Survival Time & Probit & Survival Time & Probit & Survival Time & Probit & Survival Time \\
\hline & Marginal Impact & Hazard Ratio & Marginal Impact & Hazard Ratio & Marginal Impact & Hazard Ratio & Marginal Impact & Hazard Ratio \\
\hline $\begin{array}{l}\text { Respondent (R) Has No Health } \\
\text { Insurance at Retirement Wave (RW) }\end{array}$ & $\begin{array}{ll}0.120^{\star *} & 0.161^{\star *} \\
{[0.042]} & {[0.047]} \\
\end{array}$ & & $\begin{array}{cc}0.082^{\star} & 0.108^{* *} \\
{[0.037]} & {[0.041]} \\
\end{array}$ & & $\begin{array}{cc}0.108^{*} & 0.141^{*} \\
{[0.053]} & {[0.060]} \\
\end{array}$ & & \begin{tabular}{cc|}
0.074 & $0.101^{*}$ \\
{$[0.041]$} & {$[0.046]$} \\
\end{tabular} & \\
\hline $\begin{array}{l}\text { Respondent (R) Has No Health } \\
\text { Insurance in Previous Wave (PW) }\end{array}$ & & $\begin{array}{ll}1.947^{* *} & 2.100^{* \star} \\
{[0.292]} & {[0.343]} \\
\end{array}$ & & \begin{tabular}{ll|}
$1.919^{* *}$ & $2.197^{* *}$ \\
{$[0.286]$} & {$[0.356]$} \\
\end{tabular} & & $\begin{array}{ll}2.411^{\star \star} & 2.318^{\star \star} \\
{[0.513]} & {[0.594]} \\
\end{array}$ & & $\begin{array}{ll}1.943^{\star *} & 2.218^{\star \star} \\
{[0.371]} & {[0.462]}\end{array}$ \\
\hline $\begin{array}{l}\text { R Buys Private Health Insurance at } \\
\text { RW }\end{array}$ & \begin{tabular}{cc|}
0.027 & 0.019 \\
{$[0.046]$} & {$[0.047]$} \\
\end{tabular} & & $\begin{array}{cc}0.052 & 0.035 \\
{[0.044]} & {[0.044]} \\
\end{array}$ & & $\begin{array}{cc}0.126 & 0.091 \\
{[0.065]} & {[0.065]} \\
\end{array}$ & & $\begin{array}{cc}0.105 & 0.069 \\
{[0.054]} & {[0.052]} \\
\end{array}$ & \\
\hline R Buys Private Health Insurance in $\mathrm{PW}$ & & $\begin{array}{cc}0.957 & 0.952 \\
{[0.176]} & {[0.180]} \\
\end{array}$ & & \begin{tabular}{cc|}
1.067 & 0.986 \\
{$[0.191]$} & {$[0.183]$} \\
\end{tabular} & & $\begin{array}{cc}1.47 & 1.274 \\
{[0.391]} & {[0.347]} \\
\end{array}$ & & $\begin{array}{cc}1.324 & 1.198 \\
{[0.296]} & {[0.275]} \\
\end{array}$ \\
\hline $\begin{array}{l}\text { Unsubsidized Employer Provide Health } \\
\text { Insurance at RW }\end{array}$ & \begin{tabular}{cc|}
0.034 & 0.028 \\
{$[0.033]$} & {$[0.033]$} \\
\end{tabular} & & $\begin{array}{cc}0.015 & 0.01 \\
{[0.030]} & {[0.030]} \\
\end{array}$ & & $\begin{array}{cc}0 & -0.004 \\
{[0.036]} & {[0.037]} \\
\end{array}$ & & $\begin{array}{cc}0.003 & -0.002 \\
{[0.032]} & {[0.032]} \\
\end{array}$ & \\
\hline $\begin{array}{l}\text { Unsubsidized Employer Provide Health } \\
\text { Insurance in PW }\end{array}$ & & \begin{tabular}{ll|}
$1.406^{*}$ & $1.370^{*}$ \\
{$[0.190]$} & {$[0.192]$} \\
\end{tabular} & & \begin{tabular}{ll|}
$1.424^{\star *}$ & $1.392^{\star}$ \\
{$[0.191]$} & {$[0.191]$} \\
\end{tabular} & & \begin{tabular}{cc|}
1.313 & 1.262 \\
{$[0.246]$} & {$[0.242]$} \\
\end{tabular} & & $\begin{array}{ll}1.459^{\star} & 1.397^{\star} \\
{[0.241]} & {[0.238]} \\
\end{array}$ \\
\hline R Receives Pension at RW & $\begin{array}{cc}-0.01 & -0.046 \\
{[0.023]} & {[0.024]} \\
\end{array}$ & & $\begin{array}{cc}-0.008 & -0.037 \\
{[0.021]} & {[0.022]} \\
\end{array}$ & & $\begin{array}{cc}0.063^{*} & 0.028 \\
{[0.027]} & {[0.028]} \\
\end{array}$ & & $\begin{array}{cc}0.029 & -0.002 \\
{[0.023]} & {[0.024]} \\
\end{array}$ & \\
\hline R Receives Pension in PW & & $\begin{array}{cc}0.874 & 0.754^{\star \star} \\
{[0.090]} & {[0.081]} \\
\end{array}$ & & \begin{tabular}{cc|}
0.913 & $0.775^{*}$ \\
{$[0.095]$} & {$[0.083]$} \\
\end{tabular} & & $\begin{array}{cc}1.24 & 1.019 \\
{[0.171]} & {[0.150]} \\
\end{array}$ & & $\begin{array}{cc}1.036 & 0.855 \\
{[0.129]} & {[0.111]} \\
\end{array}$ \\
\hline $\begin{array}{l}\text { Wealth Drops over } 50 \% \text { \& more than } \\
\$ 10000 \text { between RW and the Next }\end{array}$ & \begin{tabular}{cc|}
0.053 & 0.049 \\
{$[0.035]$} & {$[0.036]$} \\
\end{tabular} & & $\begin{array}{cc}0.068^{\star} & 0.066^{\star} \\
{[0.032]} & {[0.033]} \\
\end{array}$ & & $\begin{array}{cc}0.083^{*} & 0.079 \\
{[0.042]} & {[0.044]} \\
\end{array}$ & & \begin{tabular}{cc|}
$0.087^{*}$ & $0.082^{\star}$ \\
{$[0.035]$} & {$[0.036]$} \\
\end{tabular} & \\
\hline $\begin{array}{l}\text { Wealth Dropped over } 50 \% \& \text { more } \\
\text { than } \$ 10000 \text { before the PW }\end{array}$ & & \begin{tabular}{cc|}
1.284 & $1.319^{*}$ \\
{$[0.165]$} & {$[0.177]$} \\
\end{tabular} & & $\begin{array}{ll}1.294^{*} & 1.380^{*} \\
{[0.167]} & {[0.182]} \\
\end{array}$ & & $\begin{array}{cc}1.217 & 1.387 \\
{[0.222]} & {[0.267]} \\
\end{array}$ & & $\begin{array}{cc}1.328 & 1.441^{*} \\
{[0.205]} & {[0.226]} \\
\end{array}$ \\
\hline $\begin{array}{l}\text { R's Health Declines by } 2 \text { Levels or } \\
\text { more between RW and the Next }\end{array}$ & $\begin{array}{cc}0.078 & 0.045 \\
{[0.064]} & {[0.062]} \\
\end{array}$ & & $\begin{array}{cc}-0.008 & -0.029 \\
{[0.050]} & {[0.048]} \\
\end{array}$ & & $\begin{array}{cc}0.039 & 0.004 \\
{[0.068]} & {[0.064]} \\
\end{array}$ & & $\begin{array}{cc}0.005 & -0.017 \\
{[0.055]} & {[0.051]} \\
\end{array}$ & \\
\hline $\begin{array}{l}\text { R's Health Declines by } 2 \text { Levels or } \\
\text { more before the PW }\end{array}$ & & $\begin{array}{cc}0.816 & 1.112 \\
{[0.189]} & {[0.258]} \\
\end{array}$ & & $\begin{array}{cc}0.822 & 1.09 \\
{[0.182]} & {[0.239]} \\
\end{array}$ & & \begin{tabular}{cc|}
0.828 & 1.083 \\
{$[0.274]$} & {$[0.355]$} \\
\end{tabular} & & $\begin{array}{cc}0.873 & 1.181 \\
{[0.224]} & {[0.297]} \\
\end{array}$ \\
\hline $\begin{array}{l}\text { R's Household Size increases between } \\
\text { RW and the Next }\end{array}$ & $\begin{array}{|ll|}0.092^{\star} & 0.118^{\star *} \\
{[0.039]} & {[0.041]} \\
\end{array}$ & & $\begin{array}{cc}0.080^{*} & 0.100^{*} \\
{[0.037]} & {[0.039]} \\
\end{array}$ & & $\begin{array}{cc}0.097^{*} & 0.097 \\
{[0.048]} & {[0.050]} \\
\end{array}$ & & $\begin{array}{cc}0.089^{*} & 0.097^{*} \\
{[0.042]} & {[0.044]} \\
\end{array}$ & \\
\hline $\begin{array}{l}\text { R's Household Size increases before } \\
\text { the PW }\end{array}$ & & $\begin{array}{cc}0.761 & 0.739 \\
{[0.127]} & {[0.128]} \\
\end{array}$ & & $\begin{array}{cc}1.034 & 1.033 \\
{[0.154]} & {[0.160]} \\
\end{array}$ & & \begin{tabular}{cc|}
1.006 & 0.93 \\
{$[0.213]$} & {$[0.216]$} \\
\end{tabular} & & $\begin{array}{cc}1.062 & 1.055 \\
{[0.190]} & {[0.196]} \\
\end{array}$ \\
\hline $\begin{array}{l}\text { OOPM Expenses rise } 50 \% \text { \& over } \\
\$ 2,000 \text { between RW and Next (1) }\end{array}$ & \begin{tabular}{cc|}
-0.032 & -0.022 \\
{$[0.029]$} & {$[0.031]$} \\
\end{tabular} & & $\begin{array}{cc}-0.057^{*} & -0.058^{\star} \\
{[0.025]} & {[0.025]} \\
\end{array}$ & & $\begin{array}{cc}-0.023 & -0.034 \\
{[0.034]} & {[0.034]} \\
\end{array}$ & & $\begin{array}{|cc|}-0.04 & -0.04 \\
{[0.027]} & {[0.027]} \\
\end{array}$ & \\
\hline $\begin{array}{l}\text { OOPM Expenses rise } 50 \% \text { \& over } \\
\$ 2,000 \text { before PW }\end{array}$ & & $\begin{array}{cc}0.851 & 0.906 \\
{[0.114]} & {[0.125]} \\
\end{array}$ & & $\begin{array}{cc}0.935 & 1.033 \\
{[0.119]} & {[0.133]} \\
\end{array}$ & & $\begin{array}{cc}0.725 & 0.849 \\
{[0.145]} & {[0.171]} \\
\end{array}$ & & $\begin{array}{cc}0.886 & 0.993 \\
{[0.139]} & {[0.158]} \\
\end{array}$ \\
\hline $\begin{array}{l}\text { Demographic, Health, and Wealth } \\
\text { Controls }\end{array}$ & Yes & Yes & Yes & Yes & Yes & Yes & Yes & Yes \\
\hline Wave of retirement dummies & Yes & No & Yes & No & Yes & No & Yes & No \\
\hline Observations & 1755 & 2851 & 1850 & 3120 & 1119 & 1826 & 1417 & 2373 \\
\hline
\end{tabular}

Standard errors in brackets. * significant at $5 \%$; ** significant at $1 \%$

(1) OOPM is Out-of-Pocket Medical Expenses

(2) In the probit analyses, "ever unretired" is the dependent variable. In the survival time analyses, "unretired in the current wave" is the dependent variable. 
Table 13: Probit and Survival Time Analysis that Includes Wave 1 Expectations for "Working in Retirement"

\begin{tabular}{|c|c|c|c|c|c|c|c|c|}
\hline \multirow{3}{*}{ Initial HRS Cohort Full-Sample } & \multicolumn{2}{|c|}{$\begin{array}{c}\text { Self-reported } \\
\text { Retirement Status } \\
\text { Directional Definition }\end{array}$} & \multicolumn{2}{|c|}{$\begin{array}{l}\text { Rand Labor Force } \\
\text { Status } \\
\text { Directional Definition }\end{array}$} & \multicolumn{2}{|c|}{$\begin{array}{c}\text { Self-reported } \\
\text { Retirement Status } \\
\text { Full-retirement Only } \\
\text { Definition } \\
\end{array}$} & \multicolumn{2}{|c|}{$\begin{array}{c}\text { Rand Labor Force } \\
\text { Status } \\
\text { Full-retirement Only } \\
\text { Definition }\end{array}$} \\
\hline & Probit (3) & $\begin{array}{l}\text { Survival } \\
\text { Time }\end{array}$ & Probit & $\begin{array}{l}\text { Survival } \\
\text { Time }\end{array}$ & Probit & $\begin{array}{c}\text { Survival } \\
\text { Time }\end{array}$ & Probit & $\begin{array}{c}\text { Survival } \\
\text { Time }\end{array}$ \\
\hline & $\begin{array}{l}\text { Marginal } \\
\text { Impact }\end{array}$ & $\begin{array}{l}\text { Hazard } \\
\text { Ratio }\end{array}$ & $\begin{array}{l}\text { Marginal } \\
\text { Impact }\end{array}$ & $\begin{array}{l}\text { Hazard } \\
\text { Ratio }\end{array}$ & $\begin{array}{l}\text { Marginal } \\
\text { Impact }\end{array}$ & $\begin{array}{l}\text { Hazard } \\
\text { Ratio }\end{array}$ & $\begin{array}{l}\text { Marginal } \\
\text { Impact }\end{array}$ & $\begin{array}{l}\text { Hazard } \\
\text { Ratio }\end{array}$ \\
\hline $\begin{array}{l}\text { Respondent Plans to do Paid Work in } \\
\text { Retirement (1) }\end{array}$ & $\begin{array}{l}0.096^{* *} \\
{[0.021]}\end{array}$ & $\begin{array}{l}1.481^{* *} \\
{[0.146]}\end{array}$ & $\begin{array}{l}0.119^{\star *} \\
{[0.019]}\end{array}$ & $\begin{array}{l}1.724^{\star *} \\
{[0.173]}\end{array}$ & $\begin{array}{l}0.097^{* *} \\
{[0.021]}\end{array}$ & $\begin{array}{l}1.681^{* *} \\
{[0.202]}\end{array}$ & $\begin{array}{l}0.103^{* *} \\
{[0.019]}\end{array}$ & $\begin{array}{l}1.880^{* *} \\
{[0.223]}\end{array}$ \\
\hline $\begin{array}{l}\text { Respondent (R) Has No Health } \\
\text { Insurance at Retirement Wave (RW) }\end{array}$ & $\begin{array}{l}0.074^{*} \\
{[0.036]}\end{array}$ & & $\begin{array}{l}0.099^{\star *} \\
{[0.036]}\end{array}$ & & $\begin{array}{c}0.068 \\
{[0.044]}\end{array}$ & & $\begin{array}{c}0.074 \\
{[0.040]}\end{array}$ & \\
\hline $\begin{array}{l}\text { Respondent (R) Has No Health } \\
\text { Insurance in Previous Wave (PW) }\end{array}$ & & $\begin{array}{l}2.152^{\star \star} \\
{[0.291]}\end{array}$ & & $\begin{array}{l}2.013^{\star \star} \\
{[0.284]}\end{array}$ & & $\begin{array}{l}2.306^{\star *} \\
{[0.451]}\end{array}$ & & $\begin{array}{l}1.717^{\star *} \\
{[0.335]}\end{array}$ \\
\hline R Buys Private Health Insurance at RW & $\begin{array}{c}0.011 \\
{[0.041]}\end{array}$ & & $\begin{array}{c}0.048 \\
{[0.042]}\end{array}$ & & $\begin{array}{c}0.091 \\
{[0.053]}\end{array}$ & & $\begin{array}{c}0.037 \\
{[0.045]}\end{array}$ & \\
\hline R Buys Private Health Insurance in PW & & $\begin{array}{c}1.017 \\
{[0.162]}\end{array}$ & & $\begin{array}{c}0.92 \\
{[0.143]}\end{array}$ & & $\begin{array}{c}1.304 \\
{[0.283]}\end{array}$ & & $\begin{array}{c}1.011 \\
{[0.191]}\end{array}$ \\
\hline $\begin{array}{l}\text { Unsubsidized Employer Provide Health } \\
\text { Insurance at RW }\end{array}$ & $\begin{array}{c}0.05 \\
{[0.030]}\end{array}$ & & $\begin{array}{c}0.036 \\
{[0.029]}\end{array}$ & & $\begin{array}{c}0.02 \\
{[0.032]}\end{array}$ & & $\begin{array}{c}0.049 \\
{[0.031]}\end{array}$ & \\
\hline $\begin{array}{l}\text { Unsubsidized Employer Provide Health } \\
\text { Insurance in PW }\end{array}$ & & $\begin{array}{l}1.792^{\star \star} \\
{[0.222]}\end{array}$ & & $\begin{array}{l}1.880^{\star *} \\
{[0.222]}\end{array}$ & & $\begin{array}{l}1.755^{\star \star} \\
{[0.290]}\end{array}$ & & $\begin{array}{l}1.900^{\star \star} \\
{[0.269]}\end{array}$ \\
\hline R Receives Pension at RW & $\begin{array}{c}-0.059^{\star \star} \\
{[0.021]}\end{array}$ & & $\begin{array}{l}-0.037 \\
{[0.020]}\end{array}$ & & $\begin{array}{l}-0.012 \\
{[0.022]}\end{array}$ & & $\begin{array}{l}-0.034 \\
{[0.020]}\end{array}$ & \\
\hline R Receives Pension in PW & & $\begin{array}{l}0.793^{\star *} \\
{[0.065]}\end{array}$ & & $\begin{array}{l}0.737^{\star \star} \\
{[0.060]}\end{array}$ & & $\begin{array}{c}0.913 \\
{[0.093]}\end{array}$ & & $\begin{array}{l}0.712^{\star \star} \\
{[0.069]}\end{array}$ \\
\hline $\begin{array}{l}\text { Wealth Drops over } 50 \% \text { \& more than } \\
\$ 10000 \text { between RW and the Next }\end{array}$ & $\begin{array}{c}0.021 \\
{[0.031]}\end{array}$ & & $\begin{array}{c}0.046 \\
{[0.030]}\end{array}$ & & $\begin{array}{c}0.052 \\
{[0.035]}\end{array}$ & & $\begin{array}{c}0.058 \\
{[0.031]}\end{array}$ & \\
\hline $\begin{array}{l}\text { Wealth Dropped over } 50 \% \text { \& more than } \\
\$ 10000 \text { before the PW }\end{array}$ & & $\begin{array}{c}1.16 \\
{[0.123]}\end{array}$ & & $\begin{array}{c}1.151 \\
{[0.123]}\end{array}$ & & $\begin{array}{c}1.227 \\
{[0.170]}\end{array}$ & & $\begin{array}{c}1.251 \\
{[0.157]}\end{array}$ \\
\hline $\begin{array}{l}\text { R's Health Declines by } 2 \text { Levels or more } \\
\text { between RW and the Next }\end{array}$ & $\begin{array}{c}0.008 \\
{[0.053]}\end{array}$ & & $\begin{array}{l}-0.164^{\star \star} \\
{[0.033]}\end{array}$ & & $\begin{array}{l}-0.007 \\
{[0.053]}\end{array}$ & & $\begin{array}{c}-0.137^{\star \star} \\
{[0.033]}\end{array}$ & \\
\hline $\begin{array}{l}\text { R's Health Declines by } 2 \text { Levels or more } \\
\text { before the PW }\end{array}$ & & $\begin{array}{c}1.134 \\
{[0.195]}\end{array}$ & & $\begin{array}{c}0.941 \\
{[0.175]}\end{array}$ & & $\begin{array}{c}1.208 \\
{[0.261]}\end{array}$ & & $\begin{array}{c}0.904 \\
{[0.204]}\end{array}$ \\
\hline $\begin{array}{l}\text { R's Household Size increases between } \\
\text { RW and the Next }\end{array}$ & $\begin{array}{l}0.100^{\star \star} \\
{[0.037]}\end{array}$ & & $\begin{array}{l}0.089^{*} \\
{[0.035]}\end{array}$ & & $\begin{array}{l}0.084^{*} \\
{[0.041]}\end{array}$ & & $\begin{array}{c}0.04 \\
{[0.036]}\end{array}$ & \\
\hline $\begin{array}{l}\text { R's Household Size increases before } \\
\text { the PW }\end{array}$ & & $\begin{array}{c}1.016 \\
{[0.128]}\end{array}$ & & $\begin{array}{c}1.088 \\
{[0.138]}\end{array}$ & & $\begin{array}{c}1.248 \\
{[0.189]}\end{array}$ & & $\begin{array}{c}1.156 \\
{[0.172]}\end{array}$ \\
\hline $\begin{array}{l}\text { OOPM Expenses rise } 50 \% \text { \& over } \\
\$ 2,000 \text { between RW and Next (2) }\end{array}$ & $\begin{array}{l}-0.026 \\
{[0.026]}\end{array}$ & & $\begin{array}{l}-0.023 \\
{[0.025]}\end{array}$ & & $\begin{array}{l}-0.024 \\
{[0.027]}\end{array}$ & & $\begin{array}{l}-0.017 \\
{[0.026]}\end{array}$ & \\
\hline $\begin{array}{l}\text { OOPM Expenses rise } 50 \% \text { \& over } \\
\$ 2,000 \text { before PW }\end{array}$ & & $\begin{array}{c}0.993 \\
{[0.100]}\end{array}$ & & $\begin{array}{c}1.154 \\
{[0.109]}\end{array}$ & & $\begin{array}{c}0.908 \\
{[0.122]}\end{array}$ & & $\begin{array}{c}1.122 \\
{[0.127]}\end{array}$ \\
\hline $\begin{array}{l}\text { Demographic, Health, and Wealth } \\
\text { Controls }\end{array}$ & Yes & Yes & Yes & Yes & Yes & Yes & Yes & Yes \\
\hline Wave of retirement dummies & Yes & No & Yes & No & Yes & No & Yes & No \\
\hline Observations & 2440 & 5937 & 2594 & 6272 & 1806 & 4281 & 2095 & 5004 \\
\hline
\end{tabular}

Standard errors in brackets. * significant at $5 \%$; ** significant at $1 \%$

(1) Asked only in 1992 Wave

(2) OOPM is Out-of-Pocket Medical Expenses

(3) In the probit analyses, "ever unretired" is the dependent variable. In the survival time analyses, "unretired in the current wave" is the dependent variable. 
Table 14: Probit and Survival Time Analysis that Includes Wave 1 Expectations for "Working in Retirement"

\begin{tabular}{|c|c|c|c|c|c|c|c|c|}
\hline \multirow{3}{*}{$\begin{array}{l}\text { Initial HRS Cohort Under-65 } \\
\text { Sample }\end{array}$} & \multicolumn{2}{|c|}{$\begin{array}{c}\text { Self-reported } \\
\text { Retirement Status } \\
\text { Directional Definition }\end{array}$} & \multicolumn{2}{|c|}{$\begin{array}{l}\text { Rand Labor Force } \\
\text { Status } \\
\text { Directional Definition }\end{array}$} & \multicolumn{2}{|c|}{$\begin{array}{c}\text { Self-reported } \\
\text { Retirement Status } \\
\text { Full-retirement Only } \\
\text { Definition }\end{array}$} & \multicolumn{2}{|c|}{$\begin{array}{l}\text { Rand Labor Force } \\
\text { Status } \\
\text { Full-retirement Only } \\
\text { Definition }\end{array}$} \\
\hline & Probit & $\begin{array}{l}\text { Survival } \\
\text { Time }\end{array}$ & Probit & $\begin{array}{l}\text { Survival } \\
\text { Time }\end{array}$ & Probit & $\begin{array}{l}\text { Survival } \\
\text { Time }\end{array}$ & Probit & $\begin{array}{l}\text { Survival } \\
\text { Time }\end{array}$ \\
\hline & $\begin{array}{l}\text { Marginal } \\
\text { Impact }\end{array}$ & $\begin{array}{l}\text { Hazard } \\
\text { Ratio }\end{array}$ & $\begin{array}{l}\text { Marginal } \\
\text { Impact }\end{array}$ & $\begin{array}{l}\text { Hazard } \\
\text { Ratio }\end{array}$ & $\begin{array}{l}\text { Marginal } \\
\text { Impact }\end{array}$ & $\begin{array}{l}\text { Hazard } \\
\text { Ratio }\end{array}$ & $\begin{array}{l}\text { Marginal } \\
\text { Impact }\end{array}$ & $\begin{array}{l}\text { Hazard } \\
\text { Ratio }\end{array}$ \\
\hline $\begin{array}{l}\text { Respondent Plans to do Paid Work in } \\
\text { Retirement (1) }\end{array}$ & $\begin{array}{l}0.080^{* *} \\
{[0.025]}\end{array}$ & $\begin{array}{l}1.355^{\star} \\
{[0.176]}\end{array}$ & $\begin{array}{l}0.059^{* *} \\
{[0.023]}\end{array}$ & $\begin{array}{l}1.613^{\star *} \\
{[0.222]}\end{array}$ & $\begin{array}{l}0.057^{*} \\
{[0.028]}\end{array}$ & $\begin{array}{l}1.418^{*} \\
{[0.240]}\end{array}$ & $\begin{array}{l}0.060^{*} \\
{[0.024]}\end{array}$ & $\begin{array}{l}1.868^{\star \star} \\
{[0.321]}\end{array}$ \\
\hline $\begin{array}{l}\text { Respondent (R) Has No Health } \\
\text { Insurance at Retirement Wave (RW) }\end{array}$ & $\begin{array}{l}0.147^{\star \star} \\
{[0.050]}\end{array}$ & & $\begin{array}{l}0.113^{*} \\
{[0.046]}\end{array}$ & & $\begin{array}{c}0.109 \\
{[0.062]}\end{array}$ & & $\begin{array}{c}0.086 \\
{[0.051]}\end{array}$ & \\
\hline $\begin{array}{l}\text { Respondent (R) Has No Health } \\
\text { Insurance in Previous Wave (PW) }\end{array}$ & & $\begin{array}{l}1.951^{\star *} \\
{[0.349]}\end{array}$ & & $\begin{array}{l}1.832^{\star \star} \\
{[0.346]}\end{array}$ & & $\begin{array}{l}1.944^{*} \\
{[0.562]}\end{array}$ & & $\begin{array}{l}1.985^{\star \star} \\
{[0.483]}\end{array}$ \\
\hline R Buys Private Health Insurance at RW & $\begin{array}{c}-0.013 \\
{[0.047]}\end{array}$ & & $\begin{array}{c}0.014 \\
{[0.046]}\end{array}$ & & $\begin{array}{c}0.07 \\
{[0.066]}\end{array}$ & & $\begin{array}{c}0.016 \\
{[0.051]}\end{array}$ & \\
\hline R Buys Private Health Insurance in PW & & $\begin{array}{c}0.88 \\
{[0.181]} \\
\end{array}$ & & $\begin{array}{c}0.884 \\
{[0.176]} \\
\end{array}$ & & $\begin{array}{c}1.324 \\
{[0.385]} \\
\end{array}$ & & $\begin{array}{c}1.044 \\
{[0.250]} \\
\end{array}$ \\
\hline $\begin{array}{l}\text { Unsubsidized Employer Provide Health } \\
\text { Insurance at RW }\end{array}$ & $\begin{array}{c}0.036 \\
{[0.036]}\end{array}$ & & $\begin{array}{c}0.024 \\
{[0.034]}\end{array}$ & & $\begin{array}{c}-0.004 \\
{[0.039]}\end{array}$ & & $\begin{array}{c}0.022 \\
{[0.036]}\end{array}$ & \\
\hline $\begin{array}{l}\text { Unsubsidized Employer Provide Health } \\
\text { Insurance in PW }\end{array}$ & & $\begin{array}{l}1.357^{*} \\
{[0.208]}\end{array}$ & & $\begin{array}{l}1.480^{\star *} \\
{[0.219]}\end{array}$ & & $\begin{array}{c}1.161 \\
{[0.245]} \\
\end{array}$ & & $\begin{array}{l}1.543^{*} \\
{[0.274]}\end{array}$ \\
\hline R Receives Pension at RW & $\begin{array}{l}-0.054^{*} \\
{[0.026]}\end{array}$ & & $\begin{array}{l}-0.035 \\
{[0.024]}\end{array}$ & & $\begin{array}{c}0.013 \\
{[0.030]}\end{array}$ & & $\begin{array}{l}-0.005 \\
{[0.026]}\end{array}$ & \\
\hline R Receives Pension in PW & & $\begin{array}{l}0.712^{\star \star} \\
{[0.082]}\end{array}$ & & $\begin{array}{l}0.761^{*} \\
{[0.090]}\end{array}$ & & $\begin{array}{c}0.973 \\
{[0.153]} \\
\end{array}$ & & $\begin{array}{c}0.84 \\
{[0.120]} \\
\end{array}$ \\
\hline $\begin{array}{l}\text { Wealth Drops over } 50 \% \text { \& more than } \\
\$ 10000 \text { between RW and the Next }\end{array}$ & $\begin{array}{c}0.025 \\
{[0.037]} \\
\end{array}$ & & $\begin{array}{c}0.039 \\
{[0.034]}\end{array}$ & & $\begin{array}{c}0.072 \\
{[0.045]}\end{array}$ & & $\begin{array}{c}0.071 \\
{[0.038]}\end{array}$ & \\
\hline $\begin{array}{l}\text { Wealth Dropped over } 50 \% \text { \& more than } \\
\$ 10000 \text { before the PW }\end{array}$ & & $\begin{array}{c}1.197 \\
{[0.180]}\end{array}$ & & $\begin{array}{c}1.284 \\
{[0.195]} \\
\end{array}$ & & $\begin{array}{c}1.299 \\
{[0.284]} \\
\end{array}$ & & $\begin{array}{c}1.342 \\
{[0.240]}\end{array}$ \\
\hline $\begin{array}{l}\text { R's Health Declines by } 2 \text { Levels or more } \\
\text { between RW and the Next }\end{array}$ & $\begin{array}{c}0.029 \\
{[0.064]}\end{array}$ & & $\begin{array}{l}-0.038 \\
{[0.050]}\end{array}$ & & $\begin{array}{c}0.012 \\
{[0.067]}\end{array}$ & & $\begin{array}{c}-0.022 \\
{[0.054]}\end{array}$ & \\
\hline $\begin{array}{l}\text { R's Health Declines by } 2 \text { Levels or more } \\
\text { before the PW }\end{array}$ & & $\begin{array}{c}1.175 \\
{[0.282]} \\
\end{array}$ & & $\begin{array}{c}1.128 \\
{[0.281]} \\
\end{array}$ & & $\begin{array}{c}1.12 \\
{[0.388]} \\
\end{array}$ & & $\begin{array}{c}1.311 \\
{[0.376]}\end{array}$ \\
\hline $\begin{array}{l}\text { R's Household Size increases between } \\
\text { RW and the Next }\end{array}$ & $\begin{array}{l}0.129 \star \star \\
{[0.045]}\end{array}$ & & $\begin{array}{c}0.112^{*} \\
{[0.044]}\end{array}$ & & $\begin{array}{c}0.099 \\
{[0.055]}\end{array}$ & & $\begin{array}{c}0.119^{\star} \\
{[0.050]}\end{array}$ & \\
\hline $\begin{array}{l}\text { R's Household Size increases before } \\
\text { the PW }\end{array}$ & & $\begin{array}{c}0.805 \\
{[0.143]} \\
\end{array}$ & & $\begin{array}{c}1.153 \\
{[0.189]} \\
\end{array}$ & & $\begin{array}{c}1.037 \\
{[0.250]} \\
\end{array}$ & & $\begin{array}{c}1.205 \\
{[0.236]} \\
\end{array}$ \\
\hline $\begin{array}{l}\text { OOPM Expenses rise } 50 \% \text { \& over } \\
\$ 2,000 \text { between RW and Next (2) }\end{array}$ & $\begin{array}{l}-0.023 \\
{[0.032]}\end{array}$ & & $\begin{array}{l}-0.067^{\star} \\
{[0.027]}\end{array}$ & & $\begin{array}{l}-0.044 \\
{[0.035]}\end{array}$ & & $\begin{array}{c}-0.051 \\
{[0.029]}\end{array}$ & \\
\hline $\begin{array}{l}\text { OOPM Expenses rise } 50 \% \text { \& over } \\
\$ 2,000 \text { before } \mathrm{PW}\end{array}$ & & $\begin{array}{c}0.963 \\
{[0.140]}\end{array}$ & & $\begin{array}{c}1.077 \\
{[0.150]}\end{array}$ & & $\begin{array}{c}0.846 \\
{[0.185]}\end{array}$ & & $\begin{array}{c}0.995 \\
{[0.175]}\end{array}$ \\
\hline $\begin{array}{l}\text { Demographic, Health, and Wealth } \\
\text { Controls }\end{array}$ & Yes & Yes & Yes & Yes & Yes & Yes & Yes & Yes \\
\hline Wave of retirement dummies & Yes & No & Yes & No & Yes & No & Yes & No \\
\hline Observations & 1509 & 2558 & 1569 & 2678 & 984 & 1674 & 1182 & 2074 \\
\hline
\end{tabular}

Standard errors in brackets. * significant at $5 \%$; ** significant at $1 \%$

(1) Asked only in 1992 Wave

(2) OOPM is Out-of-Pocket Medical Expenses

(3) In the probit analyses, "ever unretired" is the dependent variable. In the survival time analyses, "unretired in the current wave" is the dependent variable. 